\title{
Working with broken agents: exploring computational 2D morphometrics for studying the (post)depositional history of potsherds
}

\author{
Bruno Vindrola-Padrós ${ }^{1}$, Dale Moulding ${ }^{2}$, Ciprian Astaloş ${ }^{1,3}$, Cristian Virag ${ }^{3}$, and Ulrike Sommer ${ }^{1}$
}

1. Institute of Archaeology, University College London: 31-34 Gordon Square, London, WC1H OPY, UK 2. Institute of Child Health, University College London: 30 Guilford Street, London, WC1N 1EH, UK 3. Muzeul Județean Satu Mare: Bulevardul Vasile Lucaciu 21, Satu Mare 440031, Romania

\section{Abstract}

The study of size and shape of ceramic fragments is a widespread approach used for unraveling the depositional and post-depositional history of archaeological assemblages. Similar to sediment particles, the size and shape of a potsherd are altered under conditions of abrasion, breakage, or weathering. These conditions, occurring during or after deposition, can be the product of both human and non-human agents. Thus, the analysis of dimensional and morphological changes of fragments not only points towards specific (post)depositional processes, but can also shed light on the nature of human interaction with broken pottery. By coupling a traditional sedimentological framework for shape description and a computational approach to 2D morphometrics, in this paper we present a quick, reproducible and accurate method for studying the alteration of shape and size of potsherds. Three main shape descriptors, i.e. sphericity, roundness, and convexity, were tested on a combination of experimental and Early Neolithic potsherds in Northwest Romania from contexts where the conditions of fragment alteration were known or could be safely inferred. In addition, potsherds from an Early Neolithic pit discovered at Călineşti-Oaş-Dâmbul Sfintei Mării (Satu Mare County, Romania) were analysed for determining the pit infilling process and understanding the extent of the interaction between humans and broken pots. Results from morphometric tests show the reliability of the computational technique and shape descriptors for identifying different conditions of alteration of potsherds. The Romanian assemblages analyzed provide an insight on (post)depositional processes during a key period where broken materials started to be accumulated. It shows that downslope movement was the main mechanism behind the infilling of the pit at Călineşti-Oaş-Dâmbul Sfintei Mării, and potsherds possessed a high level of erosion and fragmentation, highlighting a long span of human interaction with broken materials at this site during Early Neolithic times.

\section{Keywords}

2D Morphometrics, Potsherds, Sphericity, Roundness, Convexity, Early Neolithic

\section{Introduction}

The study of depositional and postdepositional processes has become a long-standing concern in archaeological research. Interests in these processes have been varied, and have inspired numerous research agendas (Binford, 1981; Chadwick, 2012; Chapman, 2000a, 2000b; Garrow, 2012; Hill, 1995; Richards and Thomas, 1984; Schiffer, 1987, 1983). Recent attention has been placed on understanding how deposited materials can actively shape human practices, e.g. the effects of landfill relocation on urban populations (Sosna and Brunclíková, 2017), the structuration of domestic and communal spaces (McNiven, 2013), or the accumulation of fragments as tokens of social relations that increase the status of the person or household (Chapman and Gaydarska, 2007, p. 197).

In Neolithic archaeology, the processes responsible for the filling of pits have wide-ranging consequences, as houses are normally dated by the pits accompanying them. Thus, the detailed 
chronology of the LBK-settlements of Elsloo in Limburg (Modderman, 1970), the Merzbach valley in NWGermany (Lüning, 2005; Stehli, 1994, 1989) and of Bylany in Bohemia (Pavlů, 2010, 2000), for example, are based on the seriation of ceramic from pit-fills. Pit-fills are not closed finds as defined by Oscar Montelius (1903), thus a basic tenet of archaeological dating is violated. The assumption that houses and pits are necessarily contemporary or that, at least, pits have been filled so rapidly that the finds are "practically" contemporary have been challenged repeatedly (Stäuble, 1997, 1990; Stäuble and Wolfram, 2012), and detailed microstratigraphic analyses of pit-contents have been attempted (e.g. Květina, 2005; Květina and Končelová, 2011; among others). However, the amount of materials excavated and the time needed for any detailed analysis has prevented any application of these methods on a site-level, and dating (and interpreting) through pit-contents carries on for lack of a better method.

One way of approaching these research interests is through the study of the alteration size and shape of fragments by different mechanical processes, which has been a common method used to infer (post)depositional processes in archaeological assemblages (Schiffer and Skibo, 1989, p. 101). Inspired by sedimentological studies (e.g. Krumbein, 1941a; Wadell, 1932, 1935), the basic principle behind these archaeometric (e.g. grain-size distribution analysis) and morphometric investigations is that, just like sedimentary particles (Shackley, 1978), size and shape of objects are altered under different types of abrasion and breakage processes occurring during or after deposition (Schiffer, 1987, p. 16). Morphometric studies can provide information on the mode of transportation of materials in different contexts and the environmental agents involved in these processes (Moss, 1963, 1962; Stein, 1987, p. 361), the history of particle exposure to the environment (Lira and Pina, 2009, p. 1527; Selley, 2000, p. 42), and the manner in which they are deposited (e.g. Rick, 1976; Skibo, 1987). By informing on the nature of fragment activity in the landscape we can shed light on the extent and intensity of human interaction with broken materials in different settings.

Ceramic fragments are particularly well suited for these analyses, as they are ubiquitous and abundant in archaeological sites from the Neolithic onwards. Traditionally, length, width, thickness or weight of potsherds were measured manually to provide information on processes altering assemblages like: trampling (Kirby and Kirby, 1976; Nielsen, 1991), bioturbation (Blackham, 2000), ploughing (Ammerman, 1985; Dunnell and Simek, 1995; Reynolds, 1988, 1982), downslope movement (Kirby and Kirby, 1974; Rick, 1976; Rosen, 1986, p. 50), or fluvial transportation (Skibo, 1987; Skibo and Schiffer, 1987). However, these methods of data collection are time consuming (Lira and Pina, 2009, p. 1527; Tafesse et al., 2013, p. 1101) and remain heavily dependent on just a handful of measurements, which limits the shape description of objects to a few parameters (Rohlf, 1990, p. 300; Strauss and Bookstein, 1982, p. 113).

By converting objects into 2D projections through photography and using algorithms to numerically describe the shape of these projections, computational techniques and readily available software have revolutionised the study of object shape description. These techniques have been highlighted in sedimentological studies for their accuracy, quick processing of measurements, and the reproducibility of their results (Altuhafi et al., 2013, p. 1291; Lira and Pina, 2009, p. 1529; Rodriguez et al., 2013, p. 194). More importantly, they also allow the measurement of different scales or orders of particle shape (Mitchell and Soga, 2005, p. 87), which could enable archaeologists to draw more detailed inferences on the processes behind the formation of potsherd assemblages. In this paper, we have adapted computational techniques from modern sedimentological studies towards this endeavour.

The aim of this study is to highlight the potential of 2D morphometrics to determine how archaeological deposits are formed, and to understand the processes in which potsherds are involved in 
during or after deposition. We tested three independent shape parameters, using ImageJ/Fiji and Matlab software, which include sphericity, roundness and convexity. For this purpose, a small sample of archaeological potsherds were selected from modern ploughed fields and trampled surfaces, pots recovered in situ from archaeological occupation layers, and experimentally broken vessels. Using these tested parameters, an analysis of an Early Neolithic ceramic assemblage from a pit excavated at Călineşti-Oaş-Dâmbul Sfintei Mării (Satu Mare County, Northwest Romania) was undertaken. The results show that several processes were involved in the infilling of this feature, and highlight past inhabitants had an extended relationship with broken materials. Lastly, the advantages and limitations of the use of 2D morphometrics for the study of (post)depositional processes are discussed.

\subsection{Some morphometric principles applied to the analysis of potsherds}

In the present article we follow a traditional morphometric approach as advanced by earth sciences (e.g. Mitchell and Soga, 2005; Selley, 2000). The approach is mainly focused in determining the processes in which the shape of a specimen has been modified according to their different properties and the agents involved in these processes. Different scales of shape (Figure 1) are described through ratios (e.g. length/width) that serve as a signal of the conditions in which particles were transported and deposited. The main principle of this approach to morphometrics is that the shape of a particle depends on both its microstructure and its history.

The microstructure of the material, in our case multiphased or composite ceramics (Rice, 1987, p. 348), determine its properties (e.g. hardness, strength, toughness, etc.), and for that reason has an effect on the shape of the specimen. For low-fired ceramics, like the ones used in this study, the composition (temper or inclusions) of potsherds is one of the main determinants of the microstructure (Rice, 1987, p. 348), and it constitutes an important factor in shape alteration. As brittle materials (Roesler et al., 2007, p. 71), potsherds form by the fracture of vessels, and these fractures develop differently in different composites. For example, mineral inclusions in ceramics under stress deflect crack propagation (Tite et al., 2001, p. 304), while porous ceramics like those containing organic-temper (if no fibres remain; West, 1992) tend to arrest cracks (Rice, 1987, pp. 362-363). This can result in morphological variation of fragments. Thus, this compositional information should be taken into account in morphometric analyses when dealing with compositionally varied ceramic assemblages.

In addition, when considering postdepositional and depositional processes, two main material properties of ceramics can be deemed important: surface hardness and strength/toughness. When a particle is abraded, surface hardness is a major factor in terms of shape alteration, because of its effect on "rate of deterioration of the abrasive and thus on abrasive particle geometry and contact" (Moore and King, 1980, p. 137). In archaeological ceramics hardness is mostly dependent on the firing conditions of the vessel (Rice, 1987, p. 354). Other important properties involve the resistance of the ceramic to crack initiation and propagation, i.e. strength and toughness (Müller, 2016, p. 610). In this sense, the more resistant to crack initiation and/or propagation, the more resilient the fragment will be to morphological change by breakage. Strength tests on ceramics with different tempering materials, show mineral-tempered specimens are generally stronger than organic-tempered ones (Skibo et al., 1989, p. 125).

Apart from microstructure and material properties, different types of processes affect the morphology of particles in different ways. Three common types of processes are addressed in this paper: abrasion, breakage and weathering. To paraphrase Skibo and Schiffer (1989, pp. 101-102), abrasive processes involve the removal or deformation of the ceramic's surface by mechanical contact with an abrader, and can vary from fluvial or eolian action (Balista et al., 1991; Skibo, 1987), to 
downward slope movements (Kirby and Kirby, 1974; Rick, 1976), to various human activities. A second common process is breakage or fragmentation, which involves the complete rupture of the material commonly through impact or bend stresses (Sanhueza Riquelme, 1988, p. 75). According to Lindauer (1992, p. 211), this process can be separated in primary - consisting of the original fracturing of the ceramic vessel-, and secondary - which entails the subsequent fragmentation of potsherds. Secondary breakage is frequently identified in activities like ploughing (Ammerman, 1985; Dunnell and Simek, 1995; Reynolds, 1988, 1982), bioturbation (Blackham, 2000), or trampling (Nielsen, 1991). Lastly, weathering consists of the chemical or mechanical degradation of a particle below or at the surface of the Earth (Allaby, 2013, p. 629). While chemical weathering can entail erosion of particles by dissolution, mechanical weathering involves the breakdown of a specimen through different mechanisms like salt crystallisation (Noghani et al., 2018; O'Brien, 1990) or freeze-thaw action (Texier et al., 1998). In this paper, this term is only discussed in relation to mechanical weathering.

Viewing shape as a scalar phenomenon becomes useful to unravel the specific processes through which potsherds have been involved in, which is our main interest here. Some authors (Arasan et al., 2010; Barrett, 1980; Mitchell and Soga, 2005, p. 87) have made a tripartite division of shape ranging from large scale or particle form, mezzo scale or shape of corners, and small scale or surface texture (Figure 1). Following this scalar view of shape, three independent variables are presented, which provide different information on the processes altering fragment shape.

\section{[Figure 1]}

\subsection{Shape descriptors as proxies for (post)depositional processes}

Sphericity is a large-scale shape parameter defined as "the ratio of the surface area of a sphere, of the same volume as the particle, to the actual surface area of the particle" (Wadell, 1932, p. 445). Experimental studies on quartz and rock particles have demonstrated that sphericity mainly indicates the breakage of a specimen, as "during breakage the sphericity increases more rapidly than during abrasion" (Krumbein, 1941a, p. 503). In taphonomic studies of pottery fragments, it has been shown that fragment length is reduced by breakage produced from human or non-human action like ploughing or trampling (Dunnell and Simek, 1995, p. 309; Fantuzzi, 2010, p. 33; Skibo, 1987, p. 128). Sphericity is measured here as the diameter of the largest inscribed circle over the diameter of the smallest circle that encloses the object (Cho et al., 2006, p. 591; cf. Krumbein and Sloss, 1963, p. 106; Figure 2).

Sphericity $=\frac{\text { Diameter of Maximum Inscribed Circle }}{\text { Diameter of Smallest Enclosing Circle }}$

Another macroscale parameter is the length-to-thickness ratio (S/W from now on; Kuna, 2015; Květina and Končelová, 2011; Řídký et al., 2014), which considers the platy form of potsherds. Similar to sphericity, the premise behind this parameter is that fragments break progressively until they reach a stable 'compact' size (Nielsen, 1991, p. 493). The S/W ratio is calculated by dividing the length of the specimen over its thickness. Low S/W values represent a 'compact' shape, while higher values show elongated fragments.

Roundness, a second-order shape property, can be defined as the "overall degree of curvature of the edges and corners of a particle" (Allen, 1989, p. 144). Experimental studies on sedimentary rocks and minerals have shown that the rounded edges of rock particles can be attributed to the effect of "gentle conditions of wear" (Wadell, 1935, p. 250) or abrasion (Krumbein, 1941b, p. 70). These are generally attributed to the mode of transportation of a particle (Stein, 1987, p. 362), the result of eolian (Kuenen, 1960) or fluvial action (Wadell, 1935, p. 251). Similarly, the roundness of the corners of 
fragments can be utilised as a parameter for comprehending the alteration history of archaeological assemblages (Allen, 1989; Schiffer and Skibo, 1989; Skibo, 1987; Skibo and Schiffer, 1987). For measuring roundness, the algorithm used in this paper followed Wadell's (1932) formula, which considers the degree of roundness of a particle or grain in the following way:

Roundness $=\frac{\sum_{\bar{R}}^{r}}{N}$

where $r$ is the radius of curvature of each corner, $\mathrm{R}$ the radius of the largest inscribing circle in the measuring area, and $N$ the number of corners (Figure 2).

[Figure 2]

Convexity is a small-scale descriptor of the surface texture of an object. Convexity describes the degree of roughness of the object's edges (Campaña et al., 2016, p. 75; Kuo and Freeman, 2000, p. 60). In the case of potsherds, when multiphased ceramics are broken, the resulting fragments contain 'jagged' edges, which are the result of the torturous path taken by fractures through or around some of these phases, e.g. argillaceous rock fragments, mineral inclusions, carbonised fibres, pores, among others. While these jagged or irregular edges are partly dependent on the microstructure of the pottery, if potsherds are subjected to abrasive processes, these irregularities are smoothened. On the contrary, if weathering increases the roughness of the specimen will also increase (Barrett, 1980, p. 293). For all these reasons, surface roughness has been seen as a useful parameter to determine either the abrasive history of the particle (i.e. its 'textural maturity'; Campaña et al., 2016, p. 75) or the effects of postburial weathering (Krumbein and Sloss, 1963, p. 113). Convexity is calculated here as:

Convexity $=\frac{\text { Perimeter of the Object }}{\text { Perimeter of the Convex Hull }}$

The closer the values are to 1.0, the smoother its edges, corresponding to textual maturity (Figure 2).

\section{Case study: potsherds from an Early Neolithic pit at Călineşti-Oaş-Dâmbul Sfintei Mării}

This case study forms part of an ongoing PhD project on the role of broken pottery in the Upper Tisza/Tisa Basin (Northwest Romania, Northeast Hungary and Southwest Ukraine) during the Early Neolithic, which is associated to the presence of Körös (Hungary) or Criş (Romania) pottery types. In order to apply the technique to an archaeological scenario, the site of Călineşti-Oaş-Dâmbul Sfintei Mării (Călineşti-Oaş-D.S.M. from now on) was selected. Călineşti-Oaş-D.S.M. is an open settlement located in the Oaş Depression near the joining of the Tur with the Lechinţa river in Northwest Romania (Figure 3). The topsoil in this area has been ploughed for several generations, partly affecting the archaeological material retrieved. Unlike many excavated sites in the area, records of excavations from Călineşti-OaşD.S.M. provide detailed information on the location and depths of finds, as well as complete profile sections of features identified (synthesized below). For this reasons, the site was considered optimal for examining depositional processes.

[Figure 3]

[Figure 4]

Surface surveys and excavations conducted from 1999 to 2001, estimated that the Neolithic deposits from this site must have occupied an area of 50x50m. The excavated area shown in Figure 3 comprised the central portion of the settlement, a number of four pits being identified. In the year 2000 (Németi and Astaloş, 2001) a portion of an Early Neolithic pit feature, labelled as Context 1 (CC1 from 
now on), was uncovered. The CC1 feature was cut by a 40m long trench (i.e. trench S1), and subdivided in $1 \times 1.5 \mathrm{~m}$ excavation units (Figure 4). The trench cross-sectioned the entire pit from West to East. This complete profile provided key information on the infilling of the pit. Three layers were recorded. This included the plough-zone up to $0.30 \mathrm{~m}$ in depth, and two spits inside CC1: (ii) upper ( 0.30 to $0.60 \mathrm{~m}$ deep) and (iii) lower $(0.60 \mathrm{~m}$ to bottom of feature). The upper pit layer was subdivided in units that are labelled from West to East as metres 1-2, 2-3, 4-5, 5-6, and 6-7, while in the lower pit layer units correspond to metres 2-3, 4-5 and 5-6 in this same direction (Figure 4). No sieving was performed during these excavations to retrieve small artefacts.

Open air Neolithic settlements from this region are usually located near rivers and composed of pits and rectangular wattle-and-daub houses, which contain large post-holes and often hearths (Lazarovici and Lazarovici, 2011). There are also claims that pit- and semi-subterranean houses would have been present in some parts of Romania (e.g. Lazarovici and Maxim, 1995; Luca et al., 2008). Along with some of the other reported features at Călineşti-Oaş-D.S.M., the role of CC1 pit within the settlement structure remains unclear, as it consists of an irregular-shaped pit containing relatively large quantities of ceramics but also two postholes on each end. Thus, it is too soon to rule out that this feature could have comprised a habitation structure.

A total of 7336g of ceramic fragments were found in CC1, of which 1323g were freshly broken. The remaining amount (i.e. non-freshly broken) corresponded to 262 fragments (please refer to Appendix $A$ for more information on this assemblage). The ceramics retrieved from the pit belong morphologically and stylistically to Criş phases IIIB and IVA (after Lazarovici, 1984, 1979; Virág, 2008, pp. 40, 42), which is common of Early Neolithic ceramic assemblages in Northern Romania (Astaloş et al., 2013; Luca and Suciu, 2008; Maxim, 1999; Virag, 2015). Unfortunately, radiocarbon dates from this period are few, and pottery constitutes the main chronological marker of occupations in the region. Evidence seems to suggest that in the Northern regions of Romania and Hungary this occurred at around 5800 Cal BC or later (cf. Bronk et al., 2007, p. 184; Whittle et al., 2002, p. 93).

Petrographical analyses of Early Neolithic ceramics in the Upper Tisza/Tisa region show that fabrics were commonly low-fired (ca. $600-850^{\circ} \mathrm{C}$; Kreiter, 2010, p. 271; Spataro, 2008, p. 94; Szakmány and Starnini, 2007, p. 16; Szilágyi and Szakmány, 2007, p. 40) and composed predominantly of organic temper, occasionally in conjunction with minerals like schist, sand, limestone or sandstone (Kreiter, 2010; Spataro, 2008; Szakmány and Starnini, 2007; Szilágyi and Szakmány, 2007). This was confirmed in a previous compositional study of a ceramic sample from another pit found in unit Sp1 (Figure 3), where organic and mineral inclusionsi were identified as the most prevalent components (Virag, 2008, p. 36).

Other materials found at CC1 include fragments of burnt bone, limnic quartzite blades, and fragments of groundstones (mainly querns). While the lithic material from this context has not yet been analysed, material from the nearby pit found in Sp1 sheds light on knapping activities in the area. Analysis of 1457 chipped stones from this latter feature, suggests that the site was occupied seasonally, possibly in connection to lithic raw material sources. This is indicated by the predominance of local raw materials of poor quality like limnosilicates or limnic quartzites ( $84.8 \%$ of the assemblage), the expedient use of tools, large amounts of débitage, and small amounts of blade tools in comparison to other KörösCriş sites in the Upper Tisa Basin (Chmielewski and Astaloş, 2015). The proportion of débitage to blade tools also suggests on-spot knapping activities occurred near Sp1 and, considering the relative abundance of trapeze-shaped projectile points, hunting was likely one of the main seasonal economic activities performed (Chmielewski and Astaloş, 2015, pp. 61-63).

\section{Materials and Methods}


In order to meet our aim, two objectives were set: (i) determining the suitability of the computational morphometric technique, as well as the parameters chosen, for distinguishing different mechanical processes altering the shape of potsherds, and (ii) through this tested technique identify the conditions of deposition of an Early Neolithic ceramic assemblage.

\subsection{Materials}

Two sets of materials were analysed. To comply with our first objective, a selection of Early Neolithic potsherds was established from contexts where the conditions of shape alteration were known or could be safely inferred (Table 1). This included firstly ceramic fragments obtained from modern plough-zones: fragments with organic (Hp1) and with mineral inclusions (Hp2) from Homorodu de Sus Ograda Borzului (Satu Mare County, Romania; Bader, 1968), and potsherds composed of both organic (Cp1) and organic with mineral inclusions (Cp2) retrieved from Călineşti-Oaş-D.S.M. (Virág, 2008). Other materials selected for testing were ceramic fragments with organic (Tsi1) and organic with mineral inclusions (Tsi2) from pots found in situ in the occupation layer in Tăşnad-Sere (Satu Mare County, Romania; Astaloş et al., 2013). Lastly, fragments from medium-grained (<1mm; Ep1) and fine-grained (<500 $\mu \mathrm{m}$; Ep2) mineral-tempered pottery freshly broken during a previous experiment (Vindrola-Padrós, 2015) were included as a control group. Values from shape descriptors should contrast significantly between finds from modern surfaces ( $\mathrm{Hp} 1, \mathrm{Hp} 2, \mathrm{Cp} 1$, and $\mathrm{Cp} 2$ ), i.e. more vulnerable to abrasion and breakage, and those from either freshly broken pots (Ep1, and Ep2) or pots that are broken after burial (Tsi1 and Tsi2). The size, composition and contextual information of these samples are synthesized in Table 1.

[Table 1]

To accomplish our second objective, a potsherd assemblage was sampled from the aforementioned CC1 pit context from Călineşti-Oaş-Dâmbul Sfintei Mării. Of the 262 non-freshly fractured Early Neolithic fragments retrieved from this context, 213 were sampled according to the criteria detailed in section 3.2. Fragments corresponded to the three layers, i.e. the topsoil, the upper pit layer and the lower pit layer (Figure 3), and all the units excavated, i.e. units 1-2, 2-3, 3-4, 4-5, 5-6, and 6-7 from the upper pit layer and units 2-3, 3-4, and 4-5 from the lower pit layer.

\subsection{Sampling strategy}

All pottery fragments with fresh breaks were excluded from the study. Fragments from CC1 that were excluded under this criterion were weighted in order to ensure a representative sample of material recovered (Appendix A). Secondly, following suggestions from Allen (1989, p. 145), only body sherds were selected for morphometric analysis, as rim, lug, base or pedestal fragments possess marked convexities that are more prone to abrasion (Schiffer and Skibo, 1989, p. 108) and can severely overrepresent morphological alterations that are the result of postdepositional and depositional processes. Also, fragments of less than 1000 pixels in surface area were excluded from the sample, as in ImageJ/Fiji software the margin of error increases with measurements of objects below this threshold (Takashimizu and liyoshi, 2016, p. 9). According to the resolution of images obtained, this pixel threshold corresponds in the images to fragments above $10 \mathrm{~mm}$ in length.

\subsection{Software information: ImageJ/Fiji and Matlab}

The software utilised for this study includes ImageJ/Fiji and Matlab. ImageJ or Fiji is a widely known open-source software (Ferreira and Rasband, 2012) developed by the National Institute of Health (NIH). This software was chosen for its free availability, its inbuilt shape-description algorithms and the 
ease to tailor these algorithms to our specific agenda. For our image analysis, the key feature of the software is the analysis of particles, which identifies each individual particle or fragment in a binary image, records them from top to bottom as Regions of Interest (ROIs), and measures these ROIs according to predetermined parameters. These operations can be automated, allowing the processing of hundreds of images without any user input requirements. Matlab is a technical computing language owned by Mathworks. Its image processing package provides tools for image analysis and the implementation of morphometric algorithms. In this paper, Matlab was only utilised for obtaining roundness values through a recently developed script (Zheng and Hryciw, 2015).

\subsection{Data collection}

Following the considerations presented in section 1 on the effects of microstructure on the shape of specimens, the type and size of inclusions of all sherds was macroscopically recorded and submitted to a quick qualitative hardness test following Orton and Hughes (2013). In the hardness test, fragments are scratched with a fingernail (2.5 in Mohs scale) and a piece of steel ( 6 in Mohs scale). If the fingernail produces a scratch on the surface of the specimen, it is categorized as 'soft'; if it was affected by the piece of steel but not by the fingernail, it was described as 'hard'; finally, if no mark is produced by either of the materials, the fragment is recorded as 'very hard'. This information was used to sort the material for analysis, and determine the variation caused by microstructural differences. Because of low compositional variation in the results shown in Table 1 , and the already available information on differences in strength according temper (Skibo et al., 1989, p. 125), strength/toughness tests were not performed for this paper.

For the photographs all ceramic fragments were placed sequentially on a light LED pad from top to bottom with their concave face up, which facilitates the accurate detection of the fragments' shape by the software (Figure 5). In this way the fragment number recorded by the archaeologist corresponds with the ROI number given by ImageJ/Fiji. Photographs were taken with a Cannon EOS 4OD camera and a 17-85mm lens as raw files (CR2), transformed to tiff format, and processed into 8-bit binary images through Image J/Fiji (Figure 5c). Lastly, in order to calculate the S/W ratio, the thickness of potsherds was recorded manually.

\section{[Figure 5]}

\subsection{Image analysis: measuring shape}

Despite the common use of image analysis as a viable way of establishing two-dimensional morphometrics in several disciplines (Campaña et al., 2016; Cox and Budhu, 2008; Eramo et al., 2014; García-Granero et al., 2016; Kuo and Freeman, 2000; Ros et al., 2014), there is hardly any consensus on the best way to calculate object shape (Rodriguez et al., 2012). For that reason, the sensitivity of each parameter was firstly tested to find the one most suitable for each situation or context (Rodriguez et al., 2013, p. 194). In this article, three parameters were tested, i.e. sphericity, roundness and convexity. This choice was made because all three shape descriptors are independent variables (Barrett, 1980, p. 292). A fourth parameter, i.e. length-to-thickness, was added, as it is now commonly utilised in the study of Neolithic assemblages and would serve as a useful comparison. The formulas used to calculate these shape descriptors are described in section 1.2. Lastly, other information made quickly available through ImageJ/Fiji was also recorded, such as length, width, perimeter and surface area.

Sphericity was obtained through ImageJ/Fiji software (Figure 2) according to: the Maximum Inscribed Circle plugin developed by Olivier Burri and Romain Guiet (Bioimaging and Optics Platform), 
and the Smallest Enclosing Circle macro written by Michael Schmid (2009). To complement this shape descriptor, the $\mathrm{S} / \mathrm{W}$ ratio was incorporated as a parameter.

Roundness was the only shape descriptor calculated through Matlab. Traditionally the drawbacks of this calculation were associated with the manual recording process, as it was found to be time-consuming (Krumbein, 1941b, p. 65; Powers, 1953, p. 117) and subjective when selecting corners (MacLeod, 2002, p. 32; Zheng and Hryciw, 2015, p. 499). For this reason, an automated approach was taken, which overcomes these drawbacks while still conserving its accuracy. This was accomplished through a recently developed code in Matlab (Zheng and Hryciw, 2015). The algorithm was compared to Allen's (1989) manual approach, and results are discussed in Appendix B.

Convexity was measured through an inbuilt feature of ImageJ software. The software creates a convex hull or 'rubber band' around the object of interest. Both the object's perimeter and the convex hull perimeter are then obtained (Figure 2), and calculations are made according to Equation 3.

A macro was developed to automate image processing and measurements of the fragments as specified here. It is presented as supplementary material. In this way hundreds of images, each containing between 10 to 30 fragments, could be rapidly processed in a matter of a few minutesii, and the user can verify the measurements were taken correctly. More information is detailed in Appendix $C$. Lastly, pairwise t-tests with Bonferroni correction $(P=0.05)$ were performed on samples from tests to confirm the significance of main trends observed.

\section{Results}

\subsection{Test results}

The box plots in Figure 6 present the values obtained for all three shape descriptors, and Table 2 synthesises their implications. As all the Early Neolithic sherds were soft and with medium-sized inclusions (1-2mm), data were only sorted by fragment composition (i.e. organic, mineral, and organic with mineral). Overall, the trends observed for these assemblages were concordant with expectations mentioned before, with experimentally broken pots (Ep1 and Ep2) and surface finds ( $\mathrm{Cp}$ and $\mathrm{Hp}$ ) occupying opposite ends of the spectrum for all three parameters. In particular, values from organictempered fragments display these differences very clearly, as is also attested by results from t-tests (Appendix D).

The sphericity of the fragments was high for all surface assemblages analysed, with some minor non-statistically significant variations due to compositional differences of the samples (e.g. Cp1 and $\mathrm{Cp} 2$ ). As expected, sphericity values suggest that these contexts ( $\mathrm{Hp}$ and $\mathrm{Cp}$ ) have suffered a greater degree of breakage. Experimental pots and organic-tempered pots found in situ (Tsi1), on the contrary, have very elongated fragments, as they have not been submitted to secondary breakage, and are statistically different from the rest of the samples analysed (Appendix D). The high variation in Ep1 is likely due to the manner in which the vessels were broken in the previous experiments, as some vessels impacted at a sharp angle and generated fewer amounts of spherical fragments than vessels impacting flat on the ground. High S/W values also show ploughed samples displaying more compact fragments, while low values in experimental and in situ pots indicate elongated shapes.

\section{[Figure 6]}

Roundness results display a similar trend. Higher values for roundness were observed in samples obtained from contexts where erosion is more likely to be recurrent, such as the surface finds from 
Homorodu de Sus and Călineşti-Oaş-D.S.M. Nonetheless, the Hp samples differ slightly from the latter site. Explanations for this difference can be due to more subtle differences observed in the surface hardness of the fabrics, and not picked up by our qualitative measurements. At the opposite end, freshly broken fragments (Ep1 and Ep2) presented considerably lower values for roundness, a statistically significant difference. There also seems to be considerable variation among the Ep samples, most likely due to their microstructural differences, as finer-grained pottery tends to form fractures with sharp angles (e.g. an extreme would be glass). Also, Ep2 are harder fragments and more resistant to abrasion.

Of notice are the convexity values of the fragments from Tsi1 and Tsi2 (the former being statistically different to most of the other samples), with values even lower than wares broken experimentally. As convexity signals the degree of roughness of the edges of a particle, fragments that have been submitted to abrasive processes will have smoother edges or higher convexity values. The low convexity values from Tsi1 and Tsi2 describe rough edges, and indicate they have not been abraded. The high convexity values for Ep2 could mostly be explained by their fine-grained fabric, lower porosity levels, and the stronger bonds between inclusions and clay matrix (cf. Ep1). Because of these attributes, fracture surfaces tend to be smoother, as crack deflection would be less pronounced. In contrast, values for low-fired pots indicate rougher edges. If we take into account the composition of the Tsi1 and Tsi2 potsherds which are coarser and contain a considerable amount of organic temper (therefore very porous), the same principle applies. In other words, the roughness of the fragments edges is likely to be much higher for Tsi samples partly because of their composition, which results in 'jagged' fracture patterns for organic-tempered samples.

\section{[Table 2]}

\subsection{Morphometric results from Călineşti-Oaş-D.S.M. Context 1 (CC1)}

Fragments from CC1 were all soft and $92.5 \%$ had a granulometry of one to two millimetres (Table 1). Most fragments were classified as organic with mineral inclusions, while a third of the sampled material was purely organic-tempered. Because of the small compositional variation and the fact that sample size was considerably reduced once data was sorted by square and layer, results are presented without any compositional division in Figure 7, 8, and 9. Figure 7 synthesizes information according to layer, and Figures 8 and 9 according to units and layers.

\section{[Figure 7]}

The potsherds from the ploughed surface and the pit infill (Figure 7) show differences in sphericity and S/W levels, indicating a higher degree of fragmentation of fragments in the topsoil. This is also corroborated by their size, where small fragments are more abundant in the ploughed layer despite the fact no sieving was performed during the collection of these fragments. When observing roundness and convexity values of the archaeological feature, these are higher than the ploughed layer. These results suggest that the material retrieved from the pit context has not been substantially affected by modern farming activities, but has been heavily eroded prior to their burial.

[Figure 8]

The exposition of morphometric values according to unit and layer (Figures 8 and 9) displays important trends indicating depositional processes. An increase in sphericity is observed on the western end of the upper layer of the pit, which changes abruptly towards the middle of the feature (i.e. unit 34). The latter trend is also visible in the middle portion (i.e. square 3-4) of the lower layer of the pit, where values are considerably lower than in the adjacent units. The same trend is observable for the 
length-to-thickness of fragments. Roundness values in the upper layer of the feature also increase progressively eastward until values abruptly descend in unit 4-5. Thus, in the upper layer of the feature, the fragments from the eastern end are significantly more angular. In the lower layer of the pit, once again the trend is similar to that observed in the sphericity graphs, but the eastern slope shows more rounded fragments. Convexity values in the upper pit layer, similar to roundness values, also progressively increase until very sudden low values are visible in unit 4-5, but these slightly increase towards the eastern end of the feature. Likewise in the lower pit layer, fragments have rougher surfaces in the middle portion of the feature, than those located near the western and eastern end. Lastly, the surface area of fragments in the upper layer highlights a clear trend of size sorting, with progressively increasing fragment size from West to East of the section. The lower layer also shows an abrupt increase in size towards the middle unit, with smaller fragments present near the Western and Eastern slopes.

\section{[Figure 9]}

In short, in the upper pit layer, both size and shape sorting is evident for the first three units, i.e. 1-2, 2-3 and 3-4, with progressive increase in surface area, S/W, roundness and surface texture. Secondly, with the exception of the eastern end in the upper pit layer, all fragments close to the slopes of the pit feature display high sphericity, roundness and convexity, which are markedly different to those located in the middle of the feature, i.e. units 3-4 and 4-5 in the upper pit layer and 3-4 in the lower pit layer. These results indicate a higher degree of fragmentation and erosion of sherds near slopes, also confirmed by surface area and S/W plots. Moreover, if the boxplots from Figure 6 are considered, fragments near Western and Eastern slopes possess values close to heavily eroded fragments (e.g. Cp1, Cp2). In contrast, moderate to low morphometric values from the middle portion of the feature indicate that sherds from this part of the pit experienced only a brief exposure to erosion or possible breakage. This interpretation is supported by comparing convexity values in Figure 6 , as sherds from these units lie within the range of values of freshly broken pots (Ep1 and Ep2) or pots discovered in situ (Tsi1 and Tsi2).

\section{Discussion}

\subsection{Implications of tests}

Results from tests provide important information for morphometric studies on pottery fragments. A first general observation was that organic-tempered pottery fragments appear to be more sensitive to shape alteration by different mechanical stresses, like abrasion (Schiffer and Skibo, 1989, $p$. 105; Skibo, 2013, p. 41), which makes them good indicators for identifying these processes archaeologically. This is most likely due to high porosity. Secondly, sphericity and S/W ratios have demonstrated to be useful complements to grain-size distributions to identify secondary breakage processes. Combined, these parameters incorporate an approximated three dimensional view of objects, as not only the surface projection but the thickness of fragments is taken into consideration. This is supported by experimental work on grain-size distributions in modern fields (Reynolds, 1990, 1988).

Confirming results from a previous study (Campaña et al., 2016, p. 79), convexity has proven useful for detecting the textural maturity of a specimen, i.e. if it has been heavily eroded or not. In our example it was also effective for signalling post-burial mechanical weathering. The low convexity values of pots buried in situ underlines the potential of this parameter for identifying breakage during or after burial. In other words, if confirmed by further tests, on grave finds for example, this parameter could be useful for determining the immediate burial after the breakage of objects, which in turn could help to 
corroborate arguments for so-called "structured deposition" (Chapman, 2000b; Garrow, 2012; Richards and Thomas, 1984) of singular fragments.

In line with these latter studies, the morphometric study of conjoining fragments can also present a more accurate picture of the histories individual fragments went through before deposition, especially if combined with refitting studies (e.g. Blanco-González, 2015; Chapman and Gaydarska, 2007; Květina and Končelová, 2011; Stäuble, 1990). Unfortunately, it is common practice to glue refitted fragments together. This not only constrains morphometric analyses of fragments, but also destroys one of the most diagnostic features for determining how pots and potsherds were broken: the fracture surface (Bronitsky, 1986, p. 260; Fréchette, 1990, p. 8).

\subsection{The 'depositions' of broken pots in CC1 and their implications}

Following the trends described in section 4.2, the contents of pit CC1 suggest that deposition occurred in several stages. At least two types of processes can be identified (Figure 10b). The first set of processes is responsible for depositing already broken and abraded material from the contemporary surface near the slopes of the pit. Size and shape sorting in the upper pit layer signals a downslope movement of fragments, which can be explained by a scree slope rockfall model (Kirkby and Statham, 1975; Statham, 1976). Contrary to high energy processes of mass movement, scree slope rockfall is a slow process involving the downslope fall of individual rocks (Kirkby and Statham, 1975, p. 349). As rocks fall downslope, they come in contact with the surface of the slope. Smaller rocks are easily stopped on the irregular surface of the slope, while larger ones, partly due to their higher kinetic energy (Dorren, 2003, p. 73), overcome obstacles more easily and travel longer distances (Govers and Poesen, 1998, p. 200; Kirkby and Statham, 1975, p. 353; Statham, 1976, p. 47). Thus, size sorting occurs. Shape sorting can be explained by a similar argument. As the surface of specimens becomes smoother, there is less friction between the object and the slope surface, allowing rounder and compact objects to roll down further (Rick, 1976, p. 140). While shape sorting is more indicative of rolling, size sorting signals sliding (Statham, 1976, pp. 54-55). Evidence from the upper pit layer suggests that to a certain extent both mechanisms were active in the deposition of fragments in CC1. Lastly, the prevalence of very small and heavily eroded fragments near the Western and Eastern pit slopes in the lower pit layer also suggests this process on both sides of the slope.

The second set of processes involved the much less common deposition of considerably larger, non-secondarily broken and less eroded fragments in the centre of the pit. This material could have been deposited directly by humans, for example by throwing, dumping or placing fragments into the centre of the feature. If we consider the model presented in Figure 10aiii, scenario 1 entails a patterning similar to what has been described above. Scenario 2, i.e. the 'dumping' model, large and round fragments would roll down from the middle of the feature towards the slope, while smaller and more angular fragments would remain closer to the point of deposition (Květina and Končelová, 2011, p. 58). For this reason, dumping is likely to be a much less frequent mechanism behind the deposition of fragments in this pit, occurring well after a considerable portion of the pit was already filled, and limited to just a few areas of the pit. Furthermore, the prevalence of small rounded fragments in this pit highlights a long history of fragment exposure to abrasive processes before they were slowly deposited in the pit. Certainly the causes for this second and less frequent set of processes will be further elucidated with the complete excavations of this feature in the future, when the role of CC1 within the overall settlement structure will be hopefully clarified.

[Figure 10] 
While only one feature of this site has been analysed, the results illustrate how pits can be filled by different processes. Our interpretation differs from the traditional one used to explain the formation of pit fills in Early Neolithic times (e.g. Kiely and Dunne, 2005, p. 48; Purcell, 2002, p. 68), which imply that material was purposively dumped as in modern landfills. In line with some recent micromorphological studies of Early Neolithic pits in Central and Southeastern Europe (Huisman et al., 2014; Macphail et al., 2008), our results support the idea that some pits were gradually filled by a varied set of processes and probably different agents, involving fragments with long histories, as evidenced by values indicating different abrasive and breakage processes (see also Last, 1998; Thissen, 2015). Moreover, these results indicate a longer span of interaction of human populations with broken objects before they were deposited in pits. This interpretation is also compatible with the previous understanding of the site as a temporal or seasonal occupation.

\section{Conclusion}

The aim of this paper was to explore the use of morphometric computational techniques for understanding (post)depositional processes, particularly considering the interaction between humans and broken objects. Apart from the already addressed limitations of image analysis, we found another limitation for our archaeological research questions. Sample size can shrink significantly when only body fragments are selected and fresh fractures excluded. If one becomes more meticulous in the recording the material properties of the samples, this number can be reduced even further.

Moving beyond these caveats, computational approaches to morphometrics are extremely advantageous in terms of cost (especially with open source software), reproducibility of measurements, the possibility of incorporating more suitable shape descriptors as they are developed, and the availability of large amounts of parameters that can be quickly measured. Automated approaches, using different macros and plugins enhance the processing speed even further once images have been taken, and make protocols more transparent for other researchers. There is a great ease to revisit images and monitor potential mistakes, which has not been properly addressed in traditional morphometric analysis. In addition, a great amount of information is extracted from so-called 'non-diagnostic' fragments that are abundant, but frequently disregarded in archaeological investigations. Fragment (re)use, structured deposition, taphonomy and material agency include some of the many topics that can be addressed through this technique, accompanying other methods like soil micromorphology, refitting studies and distributional analyses.

The analytical potential of 2D computational morphometrics was presented through our tests, which showed the suitability of the technique for differentiating different erosional and fragmentation processes, as well as through an archaeological scenario. The case study from Călineşti-Oaş-D.S.M. provided important information for unravelling relations between human agents and broken objects during Early Neolithic times. In this scenario, broken objects experienced an extensive interaction with human and non-human agents, which challenges the assumption that objects are immediately deposited after breakage into pits, i.e. the 'landfill analogy'. Further work is currently being performed by the leading author on a wider scale, incorporating a variety of Early Neolithic features in order to corroborate this claim. It is hoped that this future work contributes to recent redefinitions of the period (Hodder, 2017; Robb, 2013) as a moment of increasing accumulation of material remains, where broken objects occupied a more predominant role in human lifestyles than previously expected.

\section{Acknowledgements}


We would like to thank Stuart Laidlaw and Ken Walton for their assistance with photography enquiries. We also thank Jonathan Wood, Ana Paula Motta and Cecilia Vindrola-Padrós for their constructive comments. The two PhD projects from which part of this research stems are funded by University College London (UCL-ORS) and the Arts and Humanities Research Council. This project was made possible by the Institute of Child Health and the Institute of Archaeology at UCL, as well as the Muzeul Judeţean Satu Mare (Satu Mare Museum) for which we are grateful. Lastly, we wish to thank the reviewers and editors for their constructive comments on this paper.

\section{Declarations of interest: none}

i The materials sampled for this last study were unsuitable for our morphometric analysis here, as fragments had been refitted and vessels restored.

ii Depends on the memory capacity of the computer being used

iii Of course, the reader must take into consideration that Late Neolithic rondels, as the one studied by Květina and Končelová (2011), have different shapes and sizes to our CC1 pit. 


\section{References}

Allaby, M. (Ed.), 2013. A dictionary of geology and earth sciences, 4th ed. Oxford University Press, Oxford.

Allen, J.R.L., 1989. A quantitative technique for assessing the roundness of pottery sherds in water currents. Geoarchaeology 4, 143-155. https://doi.org/10.1002/gea.3340040204

Altuhafi, F., O'Sullivan, C., Cavarretta, I., 2013. Analysis of an image-based method to quantify the size and shape of sand particles. Journal of Geotechnical and Geoenvironmental Engineering 139, 1290-1307. https://doi.org/10.1061/(ASCE)GT.1943-5606.0000855

Ammerman, A.J., 1985. Plow-Zone Experiments in Calabria, Italy. Journal of Field Archaeology 12, 33-40. https://doi.org/10.1179/009346985791169544

Arasan, S., Hasiloglu, A.S., Akbulut, S., 2010. Shape Properties of Natural and Crushed Aggregate using Image Analysis. International Journal of Civil and Structural Engineering 1, 221-233. https://doi.org/10.6088/ijcser.00202010018

Astaloş, C., Sommer, U., Virag, C., 2013. Excavations of an Early Neolithic Site at Tăşnad, Romania. Archaeology International 16, 47-53. https://doi.org/10.5334/ai.1614

Bader, T., 1968. Despre figurinele antropomorfe în cadrul culturii Criş [Beitrage zur Kenntnis anthropomorpher Figurinen aus der Cris-Kultur]. Acta Musei Napocensis V, 381-388.

Balista, C., Levi, S.T., Vanzetti, A., Vidale, M., 1991. The Use of Potsherds for Interpreting Alluvial Deposits: A Case Study in the Adige River Basin. Materials Research Society Proceedings 185, 561-570. https://doi.org/10.1557/PROC-185-561

Barrett, P.J., 1980. The shape of rock particles, a critical review. Sedimentology 27, 291-303. https://doi.org/10.1111/j.1365-3091.1980.tb01179.x

Binford, L.R., 1981. Behavioral Archaeology and the "Pompeii Premise." Journal of Anthropological Research 37, 195-208. https://doi.org/10.1086/jar.37.3.3629723

Blackham, M., 2000. Distinguishing bioturbation and trampling using pottery sherd measures, Tell Fendi, Jordan. Geoarchaeology 15, 469-497. https://doi.org/10.1002/(SICI)15206548(200006)15:5<469::AID-GEA4>3.0.CO;2-G

Blanco-González, A., 2015. Past fragments: From ceramics to social practices in later prehistoric lberia. Journal of Social Archaeology 15, 342-365. https://doi.org/10.1177/1469605315591256

Bronitsky, G., 1986. The Use of Materials Science Techniques in the Study of Pottery Construction and Use. Advances in Archaeological Method and Theory 9, 209-276. https://doi.org/10.1016/B9780-12-003109-2.50008-8

Bronk, C., Higham, T., Whittle, A., Bartosiewicz, L., 2007. Radiocarbon chronology, in: Whittle, A. (Ed.), The Early Neolithic on the Great Hungarian Plain. Investigations of the Körös Culture Site of Ecsegfalva 23, County Békés. Instituti Archaeologici, Academiae Scientiarum Hungaricae, Budapest, pp. 173-188.

Campaña, I., Benito-Calvo, A., Pérez-González, A., Bermúdez de Castro, J.M., Carbonell, E., 2016. Assessing automated image analysis of sand grain shape to identify sedimentary facies, Gran Dolina archaeological site (Burgos, Spain). Sedimentary Geology 346, 72-83. https://doi.org/10.1016/j.sedgeo.2016.09.010

Chadwick, A.M., 2012. Routine Magic, Mundane Ritual: Towards a Unified Notion of Depositional Practice. Oxford Journal of Archaeology 31, 283-315. https://doi.org/10.1111/j.14680092.2012.00390.x

Chapman, J., 2000a. Fragmentation in Archaeology: People, Places, and Broken Objects in the Prehistory of South Eastern Europe. Routledge, London.

Chapman, J., 2000b. Pit-digging and Structured Deposition in the Neolithic and Copper Age. Proceedings of the Prehistoric Society 66, 61-87. https://doi.org/10.1017/S0079497X00001778

Chapman, J., Gaydarska, B.I., 2007. Parts and Wholes: Fragmentation in Prehistoric Context. Oxbow, 
Oxford.

Chmielewski, T.J., Astaloş, C., 2015. Floating stones down the Tur river. Comparative study of chipped stone assemblages from Călineşti-Oaş-Dâmbul Sfintei Mării and Méhtelek-Nádas, in: Virag, C. (Ed.), Neolithic Cultural Phenomena in the Upper Tisa Basin. Muzeul Județean Satu Mare, Satu Mare, pp. 29-74.

Cho, G.-C., Dodds, J., Santamarina, C., 2006. Particle Shape Effects on Packing Density, Stiffness, and Strength: Natural and Crushed Sands. Journal of Geotechnical and Geoenvironmental Engineering 132, 591-602.

Cox, M.R., Budhu, M., 2008. A practical approach to grain shape quantification. Engineering Geology 96, 1-16. https://doi.org/10.1016/j.enggeo.2007.05.005

Dorren, L.K.A., 2003. A review of rockfall mechanics and modelling approaches. Progress in Physical Geography 27, 69-87. https://doi.org/10.1191/0309133303pp359ra

Dunnell, R.C., Simek, J.F., 1995. Artifact Size and Plowzone Processes. Journal of Field Archaeology 22, 305-319. https://doi.org/10.1179/009346995791974242

Eramo, G., Aprile, A., Muntoni, I.M., Zerboni, A., 2014. Textural and Morphometric Analysis Applied to Holocene Pottery from Takarkori Rock Shelter (SW Libya, Central Sahara): A Quantitative Sedimentological Approach. Archaeometry 56, 36-57. https://doi.org/10.1111/arcm.12043

Fantuzzi, L., 2010. La alteración posdeposicional del material cerámico. Agentes, procesos y consecuencias para su preservación e interpretación arqueológica. Comechingonia virtual 4, $27-$ 59.

Ferreira, T., Rasband, W., 2012. ImageJ User Guide. IJ 1.46r. http://imagej.nih.gov/ij/docs/guide/userguide.pdf. Accessed October 2015.

Fréchette, V.D., 1990. Failure Analysis of Brittle Materials. The American Ceramic Society, Westerville.

García-Granero, J.J., Arias-Martorell, J., Madella, M., Lancelotti, C., 2016. Geometric morphometric analysis of Setaria italica (L.) P. Beauv. (foxtail millet) and Brachiaria ramosa (L.) Stapf. (browntop millet) and its implications for understanding the biogeography of small millets. Veget Hist Archaeobot 25, 303-310. https://doi.org/10.1007/s00334-015-0541-z

Garrow, D., 2012. Odd deposits and average practice. A critical history of the concept of structured deposition. Archaeological Dialogues 19, 85-115. https://doi.org/10.1017/S1380203812000141

Govers, G., Poesen, J., 1998. Field experiments on the transport of rock fragments by animal trampling on scree slopes. Geomorphology 23, 193-203. https://doi.org/10.1016/S0169-555X(98)00003-8

Hill, J.D., 1995. Ritual and Rubbish in the Iron Age of Wessex. A study on the formation of a specific archaeological record. Tempus Reparatum, Oxford.

Hodder, I., 2017. Things and the Slow Neolithic: the Middle Eastern Transformation. Journal of Archaeological Method and Theory 24, 1-23. https://doi.org/10.1007/s10816-017-9336-0

Huisman, D.J., Brounen, F., Lohof, E., Machiels, R., de Moor, J., van Os, B.J.H., van de Velde, P., Rensink, E., van Wijk, I.M., 2014. Micromorphological study of Early Neolithic (LBK) soil features in the Netherlands. Journal of Archaeology in the Low Countries 5, 107-133.

Kiely, J., Dunne, L., 2005. Recent archaeological excavations in the Tralee area, in: Connolly, M. (Ed.), Past Kingdoms: Recent Archaeological Research, Survey and Excavation in County Kerry. The Heritage Council and Kerry County Council, Tralee, pp. 39-64.

Kirby, A., Kirby, M., 1976. Geomorphic processes and the surface survey of archaeological sites in semiarid areas, in: Davison, D., Shackley, M. (Eds.), Geoarchaeology. Duckworth, London, pp. 229253.

Kirby, A., Kirby, M.J., 1974. Surface wash at the semi-arid break in slope. Zeitschrift für Geomorphologie 21, 151-176.

Kirkby, M.J., Statham, I., 1975. Surface Stone Movement and Scree Formation. The Journal of Geology 83, 349-362. https://doi.org/10.1086/628097 
Kreiter, A., 2010. Crafting Difference: Early Neolithic (Körös Culture) Ceramic Traditions in North-East Hungary, in: Kozlowski, J.K., Raczky, P. (Eds.), Neolithization of the Carpathian Basin: Northenmost Distribution of the Starčevo/Körös Culture. Polska Akademia Umiejętności, Kraków, pp. 266-282.

Krumbein, W.C., 1941a. The Effects of Abrasion on the Size, Shape and Roundness of Rock Fragments. The Journal of Geology 49, 482-520. https://doi.org/10.1086/624985

Krumbein, W.C., 1941b. Measurement and Geological Significance of Shape and Roundness of Sedimentary Particles. Journal of Sedimentary Research 11, 64-72. https://doi.org/10.1306/D42690F3-2B26-11D7-8648000102C1865D

Krumbein, W.C., Sloss, L.L., 1963. Stratigraphy and Sedimentation, 2nd Edition. ed. W.H. Freeman and Company, San Francisco and London.

Kuenen, P.H., 1960. Experimental Abrasion 4: Eolian Action. The Journal of Geology 68, 427-449. https://doi.org/10.1086/626675

Kuna, M., 2015. Categories of Settlement Discard, in: Kristiansen, K., Šmejda, L., Turek, J. (Eds.), Paradigm Found: Archaeological Theory - Present, Past and Future. Essays in Honour of Evžen Neustupný. Oxbow Books, Oxford, pp. 278-292.

Kuo, C.-Y., Freeman, R., 2000. Imaging Indices for Quantification of Shape, Angularity, and Surface Texture of Aggregates. Transportation Research Record: Journal of the Transportation Research Board 1721, 57-65. https://doi.org/10.3141/1721-07

Květina, P., 2005. Moznosti mikroprostorové analýzy artefaktů v archeologických objektech, in: Pavlů, I. (Ed.), Bylany Varia 3. ARUP, Praha, pp. 9-16.

Květina, P., Končelová, M., 2011. Sherds on the Map. Intra-site GIS of the Neolithic Site of Bylany (Czech Republic), in: Verhagen, P., Posluschny, A.G., Danielisová (Eds.), Go Your Own Least Cost Path. Spatial Technology and Archaeological Interpretation. Proceedings of the Session at EAA 2009, Riva Del Garda. Archaeopress, British Archaeological Reports, Oxford, pp. 55-65.

Last, J., 1998. The Residue of Yersterdays Existence: Settlement Space and Discard at Miskovice and Bylany, in: Pavlů, I. (Ed.), Bylany Varia 1. Archeologický ústav, Praha, pp. 17-46.

Lazarovici, C.M., Lazarovici, G., 2011. Architecture of the early Neolithic in Romania, in: Luca, S.A., Suciu, C. (Eds.), Early Neolithic (Starčevo-Criş) Sites on the Territory of Romania. Archaeopress, Oxford, pp. 19-36.

Lazarovici, G., 1984. Neoliticul timpuriu în România. Acta Musei Porolissensis VIII, 48-104.

Lazarovici, G., 1979. Neoliticul Banatului. Comitetul pentru Cultură şi Educație Socialistă al Județului Cluj, Cluj-Napoca.

Lazarovici, G., Maxim, Z., 1995. Gura Baciului. Monografie Arheologică. Biblioteca Musei Napocensis, Cluj-Napoca.

Lindauer, O., 1992. Ceramic Conjoinability: Orphan Sherds and Reconstructing Time, in: Hofman, J.L., Enloe, J.G. (Eds.), Piecing Together the Past: Applications of Refitting Studies in Archaeology. Tempus Reparatum, Oxford, pp. 210-216.

Lira, C., Pina, P., 2009. Automated grain shape measurments applied to beach sands. Journal of Coastal Research 56, 1527-1531.

Luca, S.A., Diaconescu, D., Suciu, C., 2008. Archaeologcial research in Miercurea Sibiului - Petriş (Sibiu County, Romania): the Starčevo-Criş level during 1997-2005 (a preliminary report). Documenta Praehistorica 35, 325-343. https://doi.org/10.4312/dp.35.22

Luca, S.A., Suciu, C., 2008. Migrations and Local Evolution in the Early Neolithic of Transylvania. The Typological-Stylistic Analysis and the Radiocarbon Data. Acta Terrae Septemcastrensis VII, 3956.

Lüning, J., 2005. Bandkeramische Hofplätze und absolute Chronologie der Bandkeramik, in: Lüning, J., Frirdich, C., Zimmermann, A. (Eds.), Die Bandkeramik Im 21. Jahrhundert. Symposium in Der 
Abtei Brauweiler Bei Köln Vom 16.9.-19.9.2002. Internationale Archäologie,

Arbeitsgemeinschaft, Symposium, Tagung, Kongress 7. Leidorf, Rahden/Westfalen, pp. 49-74.

Macphail, R.I., Haită, C., Bailey, D.W., Andreescu, R., Mirea, P., 2008. The soil micromorphology of enigmatic Early Neolithic pit-features at Măgura, southern Romania. Studii de Preistorie 5, 6177.

Maxim, Z., 1999. Neo-Eneoliticul din Transilvania. Muzeul Naţional de Istorie a Transilvaniei, ClujNapoca.

McNiven, I.J., 2013. Ritualized Middening Practices. J Archaeol Method Theory 20, 552-587. https://doi.org/10.1007/s10816-012-9130-y

Mitchell, J.K., Soga, K., 2005. Fundamentals of soil behavior, 3rd ed. Wiley, New York.

Modderman, P.J.R., 1970. Linearbandkeramik aus Elsloo und Stein. Analecta Praehistorica Leidensia 3, $1-244$.

Montelius, O., 1903. Die Typologische Methode: Älteren kulturperioden im Orient und in Europa. K.L. Beckmans Buchdruckerei, Stockholm.

Moore, M.A., King, F.S., 1980. Abrasive wear of brittle solids. Wear 60, 123-140. https://doi.org/10.1016/0043-1648(80)90253-7

Moss, A.J., 1963. The physical nature of common sandy and pebbly deposits. Part II. American Journal of Science 261, 297-343. https://doi.org/10.2475/ajs.261.4.297

Moss, A.J., 1962. The physical nature of common sandy and pebbly deposits. Part I. American Journal of Science 260, 337-373. https://doi.org/10.2475/ajs.260.5.337

Müller, N.S., 2016. Mechanical and Thermal Properties, in: Hunt, A. (Ed.), The Oxford Handbook of Archaeological Ceramic Analysis. Oxford University Press, Oxford, pp. 603-624.

Németi, J., Astaloş, C., 2001. Călineşti-Oaş-Dâmbul Sfintei Mării, in: Angelescu, M.V., Borş, C., Târnoveanu, I.O. (Eds.), Cronica Cercetărilor Arheologice Din România, Campania 2000: A XXXV-a Ediţie a Sesiunii Anuale de Cercetare Arheologică, Suceava 2001. CIMEC - Institutul de Memorie Culturală, Bucureşti, pp. 60-61.

Nielsen, A.E., 1991. Trampling the Archaeological Record: An Experimental Study. American Antiquity 56, 483-503. https://doi.org/10.2307/280897

Noghani, S., Amiri, M.C., Emami, M., 2018. A new approach to the desalination process of archaeological potteries. Mediterranean Archaeology and Archaeometry 18, 255-267. https://doi.org/10.5281/zenodo.1165366

O'Brien, P., 1990. An experimental study of the effects of salt erosion on pottery. Journal of Archaeological Science 17, 393-401. https://doi.org/10.1016/0305-4403(90)90004-O

Orton, C., Hughes, M., 2013. Pottery in Archaeology, 2nd ed. Cambridge University Press, Cambridge.

Pavlů, I., 2010. Činnosti na neolitickém sídlišti Bylany. Prostorová analýza keramiky. Archeologický ústav AV ČR, Praha.

Pavlů, I., 2000. Life on a Neolithic Site. Bylany - Situational Analysis of Artefacts. Archeologický ústav AV ČR, Praha.

Purcell, A., 2002. Excavation of three Neolithic houses at Corbally, Kilcullen, Co. Kildare. The Journal of Irish Archaeology 11, 31-75.

Reynolds, P.J., 1990. Sherd Movement in the Ploughzone. Phase V, Butser Ancient Farm Yearbook 1990. Butzer Farm.

Reynolds, P.J., 1988. Sherd movement in the ploughzone-physical data base into computer simulation, in: Rahtz, S.P.Q. (Ed.), Computer and Quantitative Methods in Archaeology. British Archaeological Series, Oxford, pp. 201-219.

Reynolds, P.J., 1982. The ploughzone. Festschrift zum 100, 315-341.

Rice, P.M., 1987. Pottery analysis: a sourcebook. University of Chicago Press, Chicago.

Richards, C., Thomas, J., 1984. Ritual activity and structured deposition in Later Neolithic Wessex, in: 
Bradley, R., Gardiner, J. (Eds.), Neolithic Studies: A Review of Some Current Research.

Archaeopress, British Archaeological Reports, Oxford, pp. 189-218.

Rick, J.W., 1976. Downslope movement and archaeological intrasite spatial analysis. American Antiquity 41, 133-144. https://doi.org/10.2307/279164

Řídký, J., Končelová, M., Šumberová, R., Limburský, P., Květina, P., 2014. How Were Neolithic Ditches

Filled In? Deposition Study of Two Enclosures from Bohemia. Eur. J. Archaeol. 17, 579-601. https://doi.org/10.1179/1461957114Y.0000000063

Robb, J., 2013. Material Culture, Landscapes of Action, and Emergent Causation: A New Model for the Origins of the European Neolithic. Current Anthropology 54, 657-683. https://doi.org/10.1086/673859

Rodriguez, J., Edeskär, T., Knutsson, S., 2013. Particle shape quantities and measurement techniques: a review. The Electronic Journal of Geotechnical Engineering 18/A, 169-198.

Rodriguez, J.M., Johansson, J.M.A., Edeskar, T., 2012. Particle Shape Determination by Two-Dimensional Image Analysis in Geotechnical Engineering, in: Proceedings of Nordic Conference on Soil Mechanics and Geotechniques. Danish Geotechnical Society, Copenhagen, pp. 207-218.

Roesler, J., Harders, H., Baeker, M., 2007. Mechanical Behaviour of Engineering Materials. Springer, Berlin.

Rohlf, F.J., 1990. Morphometrics. Annual Review of Ecology and Systematics 21, 299-316. https://doi.org/10.1146/annurev.es.21.110190.001503

Ros, J., Evin, A., Bouby, L., Ruas, M.-P., 2014. Geometric morphometric analysis of grain shape and the identification of two-rowed barley (Hordeum vulgare subsp. distichum L.) in southern France. Journal of Archaeological Science 41, 568-575. https://doi.org/10.1016/j.jas.2013.09.015

Rosen, A.M., 1986. Cities of Clay. The Geoarchaeology of Tells. University of Chicago Press, Chicago.

Sanhueza Riquelme, L., 1988. Antecedentes y proposición metodológica para el estudio de huellas de alteración en cerámica. Conserva 2, 69-79.

Schiffer, M.B., 1987. Formation processes of the archaeological record. University of New Mexico Press, Albuquerque, NM.

Schiffer, M.B., 1983. Toward the Identification of Formation Processes. American Antiquity 48, 675-706. https://doi.org/10.2307/279771

Schiffer, M.B., Skibo, J.M., 1989. A Provisional Theory of Ceramic Abrasion. American Anthropologist 91, 101-115. https://doi.org/10.1525/aa.1989.91.1.02a00060

Schmid, M., 2009. Smallest Enclosing Circle. ImageJ Macros.

Selley, R.C., 2000. Applied Sedimentology, Second Edition. ed. Academic Press, London.

Shackley, M.L., 1978. The Behaviour of Artefacts as Sedimentary Particles in a Fluviatile Environment. Archaeometry 20, 55-61. https://doi.org/10.1111/j.1475-4754.1978.tb00212.x

Skibo, J.M., 2013. Understanding Pottery Function, in: Understanding Pottery Function, Manuals in Archaeological Method, Theory and Technique. Springer New York, pp. 1-25.

Skibo, J.M., 1987. Fluvial Sherd Abrasion and the Interpretation of Surface Remains on Southwestern Bajadas. North American Archaeologist 8, 125-141. https://doi.org/10.2190/0J02-23DB-34HV2PFV

Skibo, J.M., Schiffer, M.B., 1987. The effects of water on processes of ceramic abrasion. Journal of Archaeological Science 14, 83-96. https://doi.org/10.1016/S0305-4403(87)80008-0

Skibo, J.M., Schiffer, M.B., Reid, K.C., 1989. Organic-Tempered Pottery: An Experimental Study. American Antiquity 54, 122-146. https://doi.org/10.2307/281335

Sosna, D., Brunclíková, L., 2017. Introduction, in: Sosna, D., Brunclíková, L. (Eds.), Archaeologies of Waste: Encounters with the Unwanted. Oxbow Books, Oxford, pp. 1-13.

Spataro, M., 2008. Early Neolithic pottery production in Romania: Gura Baciului and Şeuşa La-Cărarea Morii (Transylvania), in: Bailey, D., Whittle, A., Hofmann, D. (Eds.), Living Well Together? 
Settlement and Materiality in the Neolithic of South-East and Central Europe. Oxbow Books, Oxford, pp. 91-100.

Statham, I., 1976. A Scree Slope Rockfall Model. Earth Surface Processes 1, 43-62.

Stäuble, H., 1997. Häuser, Gruben und Fundverteilung, in: Lüning, J. (Ed.), Eine Siedlung Der Ältesten Bandkeramik in Bruchenbrücken, Stadt Friedberg/Hessen, Aüs Dem Seminar Fur- Und Frühgeschichte Der Universität Frankfurt/M. Universitätsforschungen zur Prähistorischen Archäologie, Bonn, pp. 17-50.

Stäuble, H., 1990. Die ältestbandkeramische Grabenanlage in Eitzum, Ldkr. Wolfenbüttel: Überlegungen zu Verfüllung und Interpretation von Befunden. Jahresschrift für mitteldeutsche Vorgeschichte 73, 331-344.

Stäuble, H., Wolfram, S., 2012. Taphonomie heute: Reanimation erwünscht. Studien zur Bandkeramik, in: Link, T., Schimmelpfennig, D. (Eds.), Taphonomische Forschungen (Nicht Nur) Zum Neolithikum. Beiträge Zur Sitzung Der AG Neolithikum Im Rahmen Der 80. Verbandstagung Des West- Und Süddeutschen Verbands Für Altertumsforschung e. V. in Nürnberg Am 26. Und 27. Mai 2010. Welt und Erde, Kerpen, pp. 33-55.

Stehli, P., 1994. Chronologie der Bandkeramik im Merzbachtal, in: Lüning, J. (Ed.), Die Bandkeramik Im Merzbachtal Auf Der Aldenhovener Platte, Rheinische Ausgrabungen. Rheinland-Verlag, Köln, pp. 79-191.

Stehli, P., 1989. Merzbachtal - Umwelt und Geschichte einer bandkeramischen Siedlungskammer. Germania 67, 51-76.

Stein, J.K., 1987. Deposits for Archaeologists. Advances in Archaeological Method and Theory 11, 337395. https://doi.org/10.1016/B978-0-12-003111-5.50009-9

Strauss, R.E., Bookstein, F.L., 1982. The Truss: Body Form Reconstructions in Morphometrics. Syst Biol 31, 113-135. https://doi.org/10.1093/sysbio/31.2.113

Szakmány, G.Y., Starnini, E., 2007. Archaeometric Research on the First Pottery Production in the Carpathian Basin: Manufacturing Traditions of the Early Neolithic, Körös Culture Ceramics. Archeometriai Múhely 2, 5-19.

Szilágyi, V., Szakmány, G.Y., 2007. Petrographic and Geochemical Study of Cermics of Neolithic Settlements on the Northern Boundary of the Great Hungarian Plain - Tiszaszőlős-Domaháza (Körös Culture) and Füzesabony-Gubakú (ALP Culture, Szatmár Group). Archeometriai Mühely 3, 31-46.

Tafesse, S., Robison Fernlund, J.M., Sun, W., Bergholm, F., 2013. Evaluation of image analysis methods used for quantification of particle angularity. Sedimentology 60, 1100-1110. https://doi.org/10.1111/j.1365-3091.2012.01367.x

Takashimizu, Y., liyoshi, M., 2016. New parameter of roundness R: circularity corrected by aspect ratio. Prog. in Earth and Planet. Sci. 3, 1-16. https://doi.org/10.1186/s40645-015-0078-x

Texier, J.P., Bertran, P., Coutard, J.P., Francou, B., Gabert, P., Guadelli, J.L., Ozouf, J.C., Plisson, H., Raynal, J.P., Vivent, D., 1998. TRANSIT, an experimental archaeological program in periglacial environment: Problem, methodology, first results. Geoarchaeology 13, 433-473. https://doi.org/10.1002/(SICI)1520-6548(199806)13:5<433::AID-GEA1>3.0.CO;2-1

Thissen, L., 2015. Ceramics from an Early Neolithic (Criş I) site in S Romania: 'Buduiasca-Boldul lui Moş Ivănuş. Buletinul Muzeului Judeţean Teleorman 7, 5-44.

Tite, M.S., Kilikoglou, V., Vekinis, G., 2001. Strength, Toughness and Thermal Shock Resistance of Ancient Ceramics, and Their Influence On Technological Choice. Archaeometry 43, 301-324. https://doi.org/10.1111/1475-4754.00019

Vindrola-Padrós, B., 2015. The Narratives of Broken Pots: Understanding Pottery Breakage through an Experimental Approach (Thesis (MA)). University College London, London.

Virag, C., 2015. Some aspects about the Neolithic settlement from Tăşnad (Satu Mare County, Romania), 
in: Virag, C. (Ed.), Neolithic Cultural Phenomena in the Upper Tisa Basin. Muzeul Județean Satu Mare, Satu Mare, pp. 97-126.

Virag, C., 2008. Materiale ceramice neolitice de la Călineşti-Oaş-Dâmbul Sfintei Mării. Studii şi Comunicări Satu Mare XXV, 35-44.

Wadell, H., 1935. Volume, Shape, and Roundness of Quartz Particles. The Journal of Geology 43, 250280. https://doi.org/10.1086/624298

Wadell, H., 1932. Volume, Shape, and Roundness of Rock Particles. The Journal of Geology 40, 443-451. https://doi.org/10.1086/623964

West, S.M., 1992. Temper, thermal shock and cooking pots: A study of tempering materials and their physical significance in prehistoric and traditional cooking pottery (Thesis (MSc)). The University of Arizona, Ann Arbor.

Whittle, A., Bartosiewicz, L., Borič, D., Petitt, P., Richards, M., 2002. In the beginning: New radiocarbon dates for the early Neolithic in northern Serbia and south-east Hungary. Anateus 25, 63-117.

Zheng, J., Hryciw, R.D., 2015. Traditional soil particle sphericity, roundness and surface roughness by computational geometry. Géotechnique 65, 494-506. https://doi.org/10.1680/geot.14.P.192

\section{List of Figures}

- $\quad$ Figure 1: Description of different scales of particle shape (after Mitchell and Soga 2005).

- Figure 2: Synthesis of features extracted from images for calculating the different shape descriptors utilised. Features were obtained through ImageJ/Fiji (a, c) and Matlab (b) software.

- Figure 3: Map of Early Neolithic sites in Northwest Romania and Northeast Hungary with sites of interest: (1) Călineşti-Oaş-Dâmbul Sfintei Mării, (2) Homorodu de Sus - Ograda Borzului, (3) Tăşnad Sere, (4) Suplacu de Barcău, (5) Gura Baciului, (6) Méhtelek-Nádas, (7) Nagyecsed, and (8) Endrőd 119.

- Figure 4: Plan view of excavated features at Călineşti-Oaş-D.S.M. (above; after Chmielewski and Astaloş 2015), with the plan and profile of pit feature 'Context 1' (CC1; below).

- Figure 5: Procedures for image collection and processing: (A) photography layout, (B) the disposition of fragments on the white background, and $(C)$ the transformation of photographs into binary images.

- Figure 6: Results obtained from tests of our computational morphometric approach.

- Figure 7: Results of size and shape analysis of CC1 pit according to the different layers excavated: the ploughed topsoil, the upper pit layer (UPL), and the lower pit layer (LPL). The difference in sample size for 'Upper Pit Layer' (i.e. 127) with the total in Figure 8 (i.e. 122) is due to the loss of the spatial information of five fragments within the layer.

- Figure 8: Results of size and shape analysis of the CC1 'Upper Pit Layer' sorted according to excavation units in metres from West to East (i.e. 1-2, 2-3, 3-4, 4-5, 5-6, 6-7).

- Figure 9: Results of size and shape analysis of the CC1 'Lower Pit Layer' sorted according to excavation units in metres from West to East (i.e. 2-3, 3-4, 4-5).

- Figure 10: Models of pit deposition according to Květina and Končelová (2011) adapted to CC1 (A), and final interpretation of the filling process of CC1 (B).

\section{List of Tables}

- Table 1: Sample size and fabric composition of potsherds used for the morphometric test and for the archaeological case study (i.e. material from pit CC1).

- Table 2: Synthesis of findings from morphometric tests.

\section{Supplementary Material:}


- Appendix A: Percentages of excluded and sampled fragments from CC1.

- Appendix B: Roundness values of Roman fragments obtained by comparing Allen's (1989) manual approach and Zheng and Hryciw's (2015) automated computational approach, using Figure 1 in Allen (1989). Notice that, while both approaches obtain different values, the order of fragments from rounder to angular is similar: C-D-A-B-E for the manual and C-D-B-A-E for the automated approach. Different values can be explained by the higher sensitivity of the algorithm developed by Zheng and Hryciw (2015) for detecting the corners of fragments.

- Appendix C: Script developed by Dale Moulding. The macro automates the processing of images in binary format and calculates feret or calliper diameter, minferet or minimum calliper diameter, perimeter, area, sphericity, and convexity of particles according to the layout detailed in the text. The output includes a csv file with results of all specified parameters, the ROIs and their labels selected by the software, and an image in jpeg format displaying the region of interest and the parameters used to calculate sphericity (i.e. smallest enclosing circle and maximum inscribed circle).

- Appendix D: Pairwise t-tests results of morphometric tests. 
Morphology (large scale)

Shape of Corners

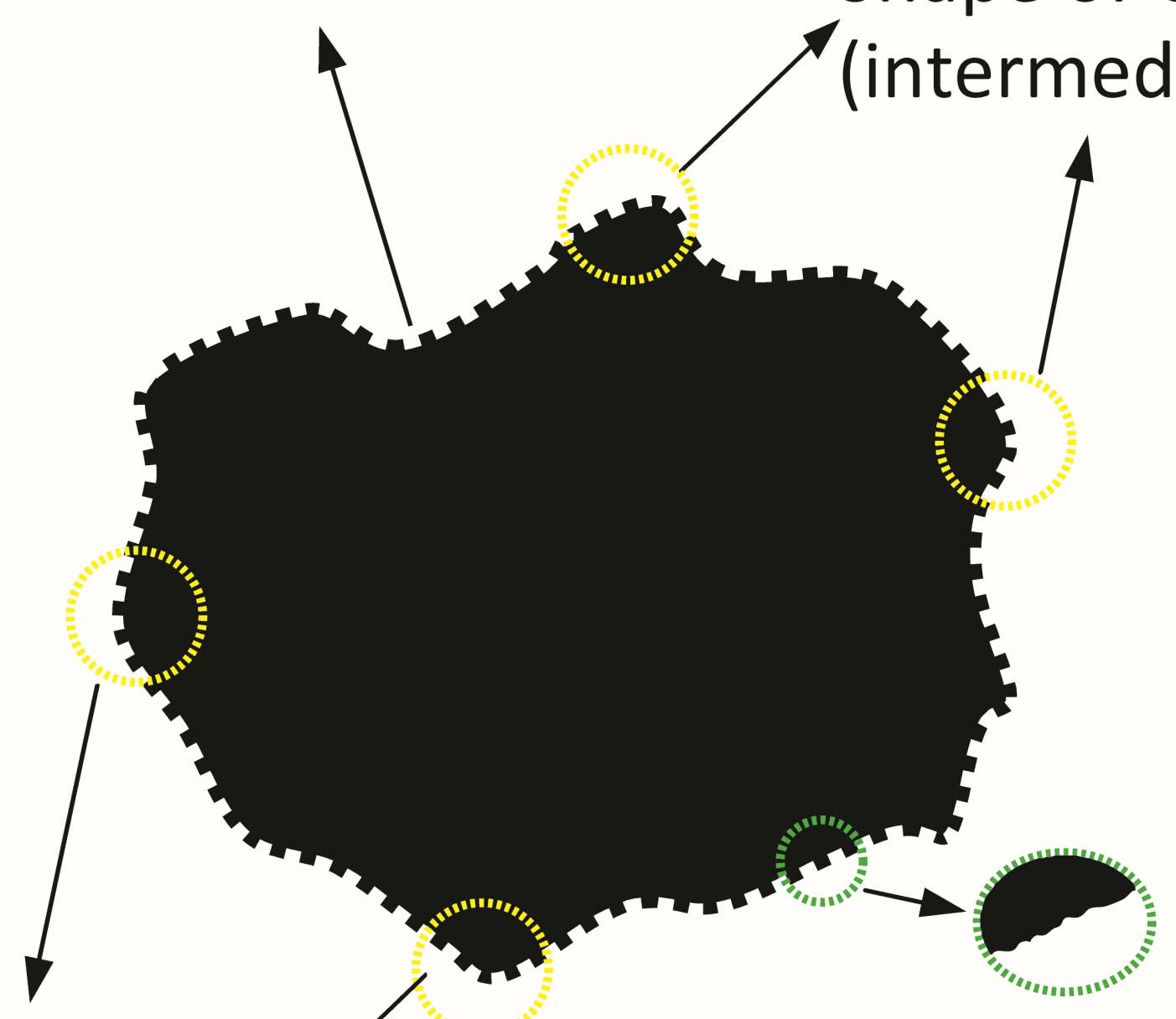

Shape of Corners

Surface Texture (intermediate scale) (small scale) 
Sphericity (large scale)

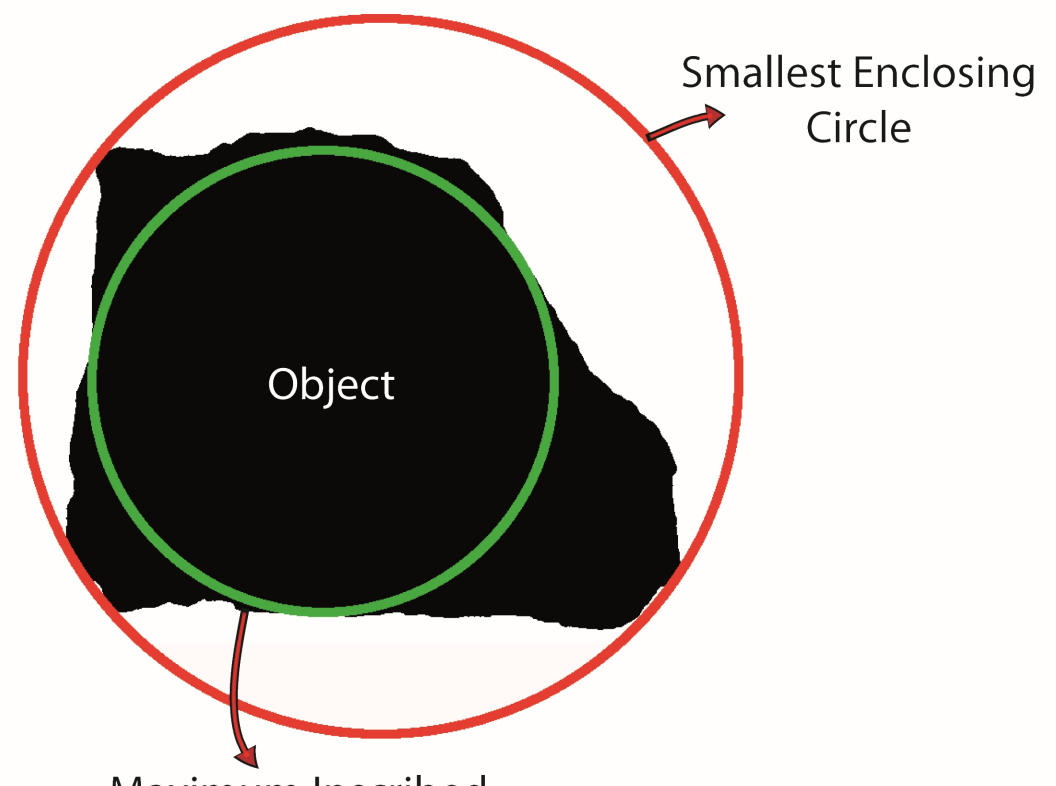

Roundness (intermediate scale)

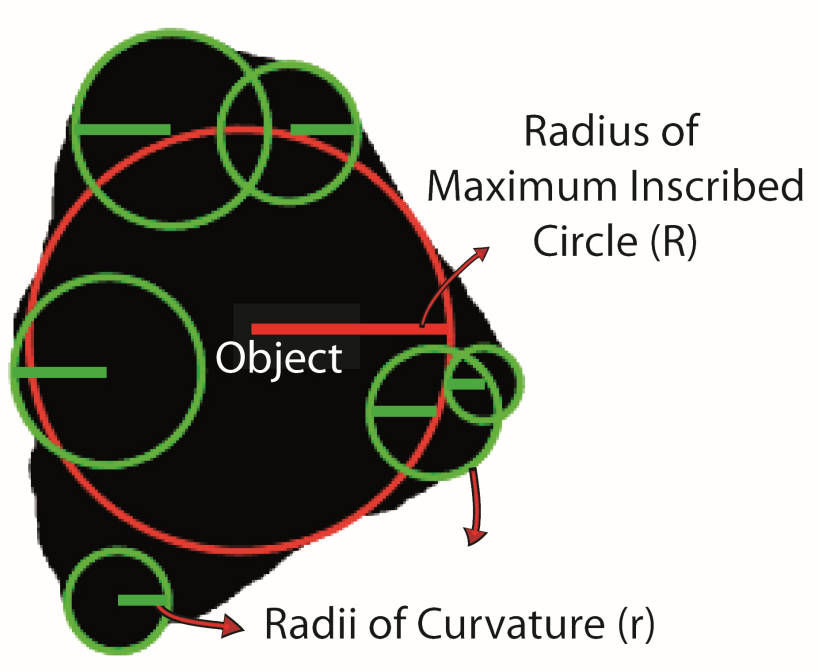

Maximum Inscribed Circle

Convexity (small scale)

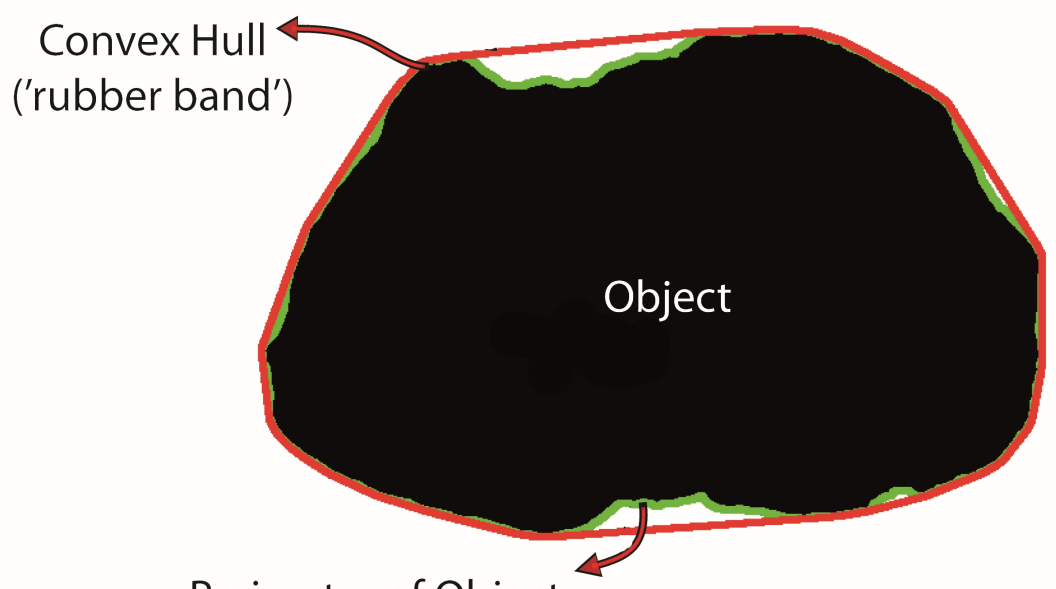

Perimeter of Object 


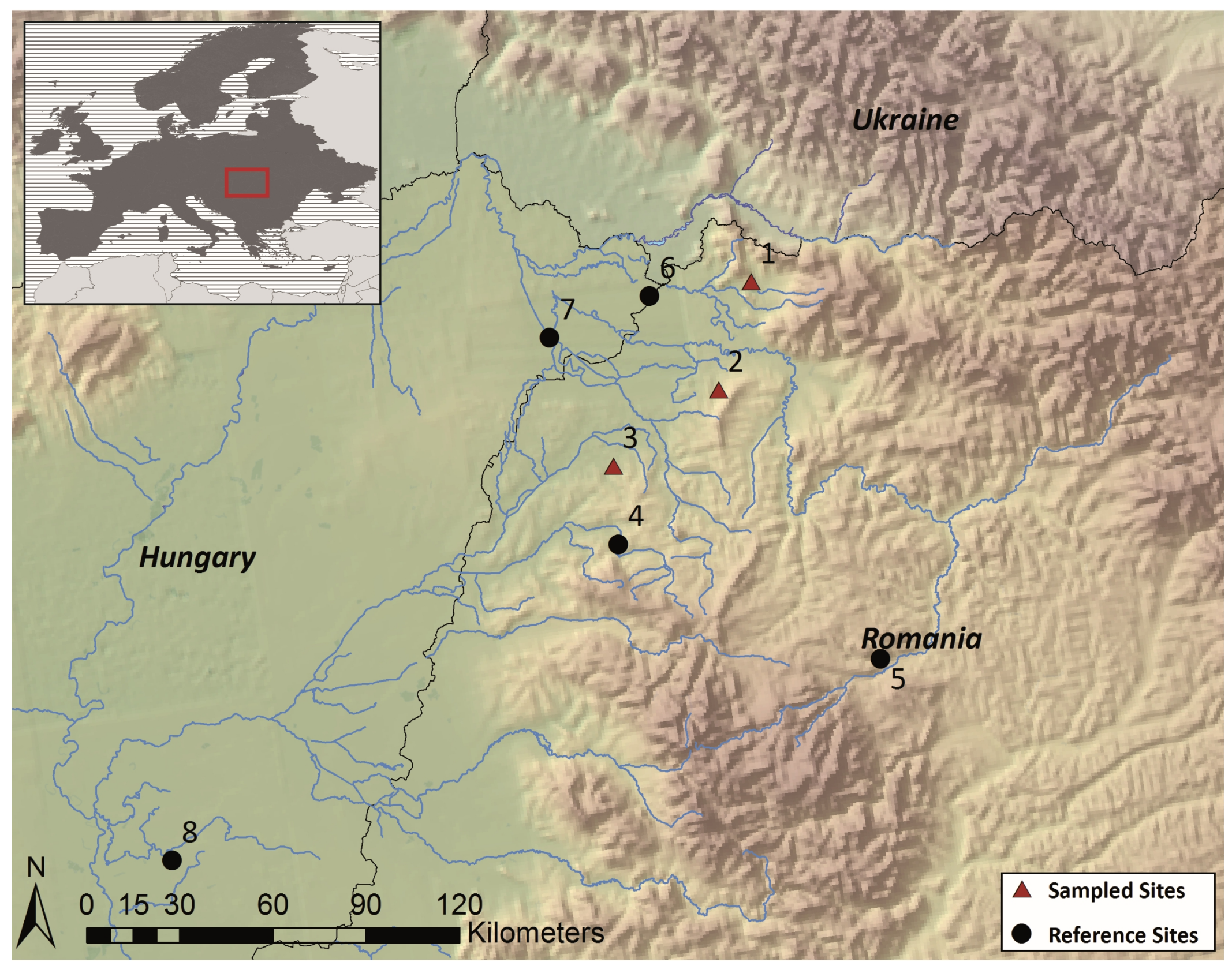





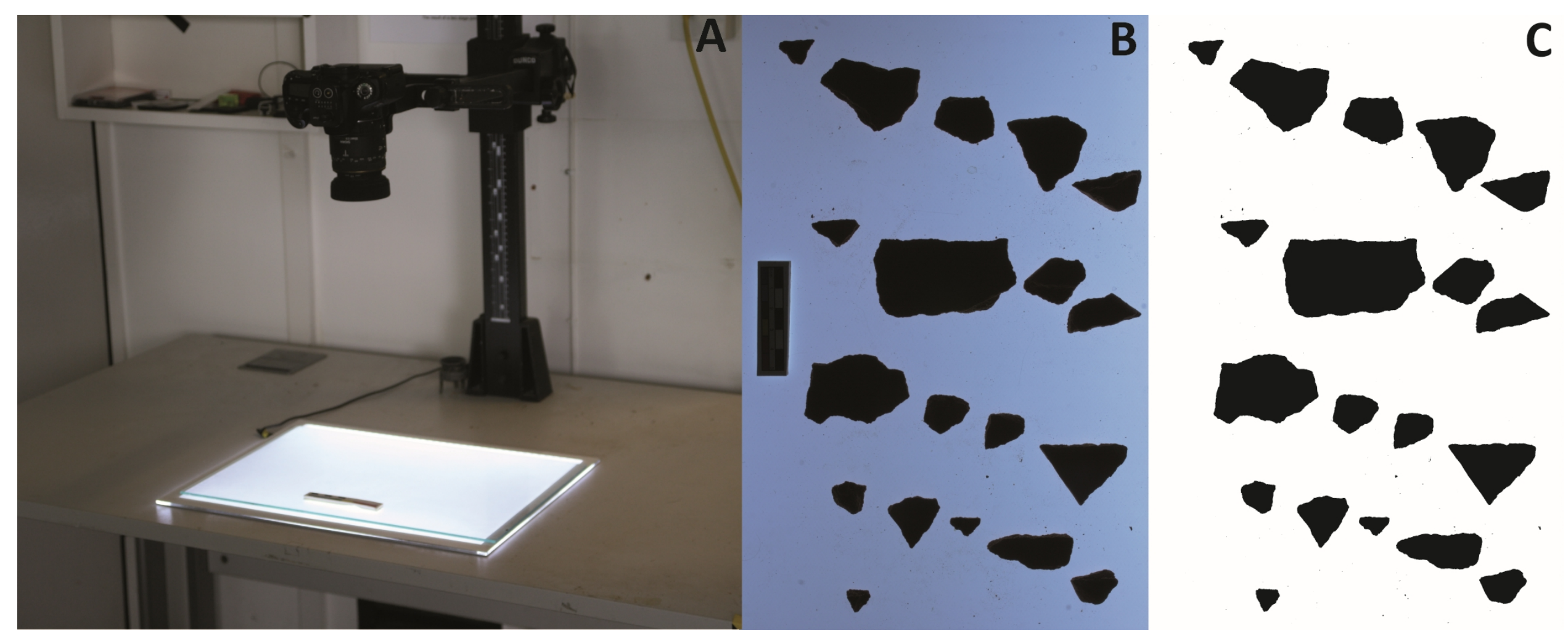


Sphericity

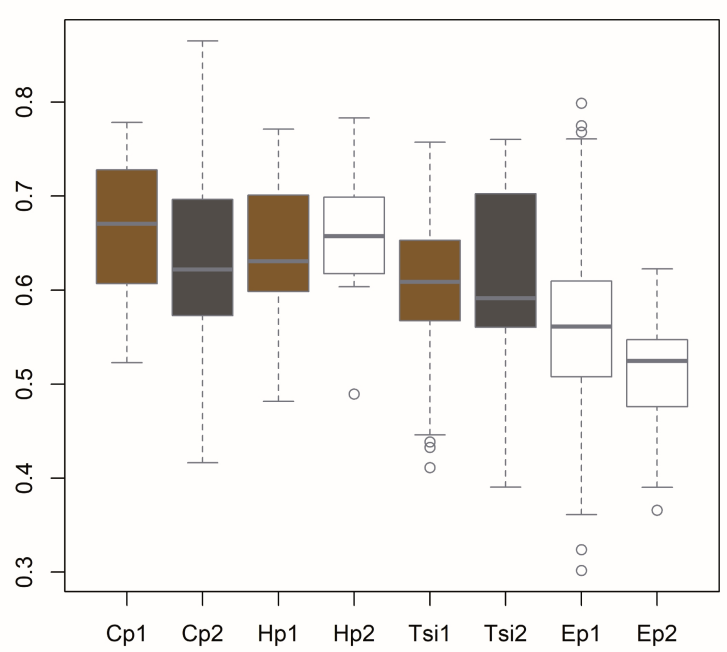

Roundness

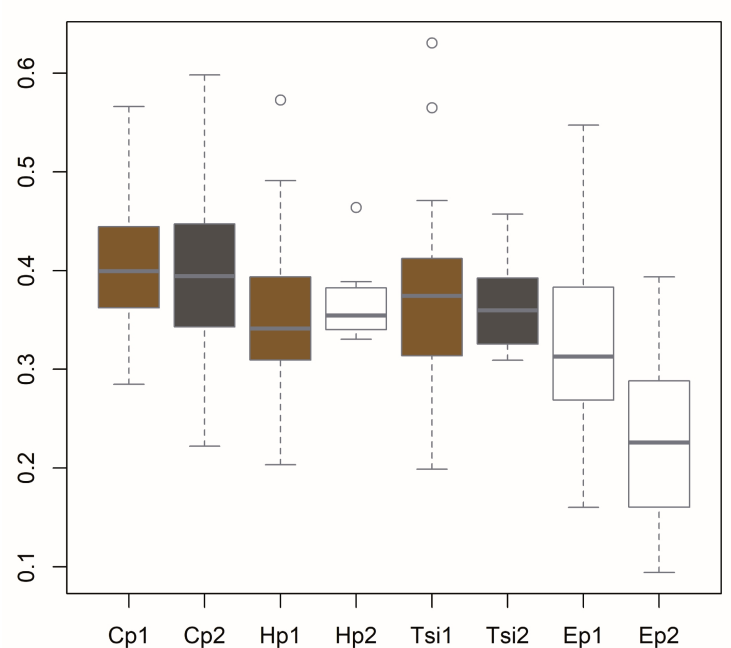

Length-to-Thickness Ratio (S/W)

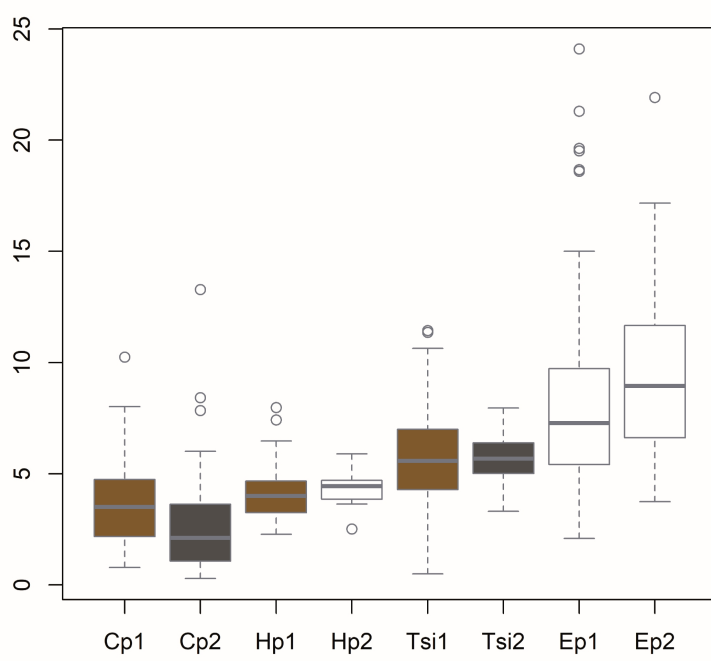

Convexity

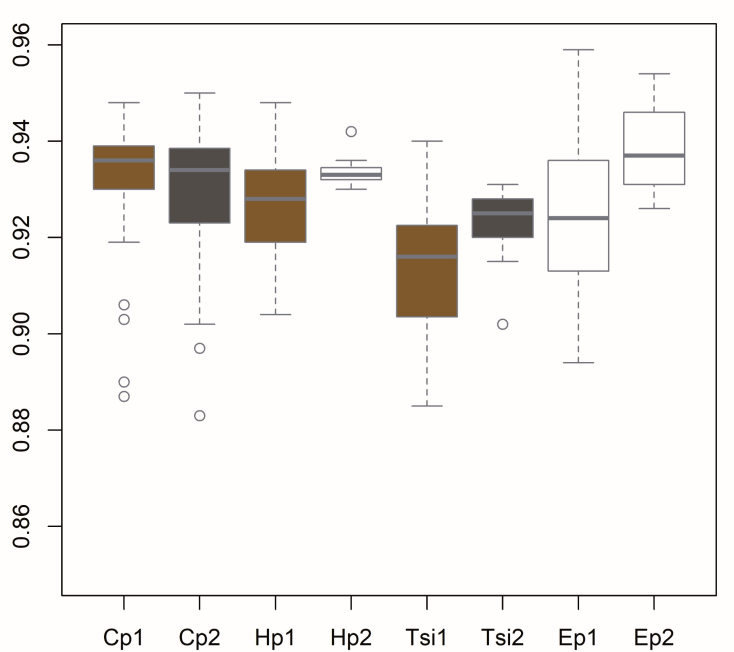

\begin{tabular}{c|c}
\multicolumn{2}{c}{ Sample Size $(\mathrm{n})$} \\
Cp1 & 41 \\
\hline Cp2 & 56 \\
\hline Hp1 & 57 \\
\hline Hp2 & 7 \\
\hline Tsi1 & 31 \\
\hline Tsi2 & 10 \\
\hline Ep1 & 146 \\
\hline Ep2 & 17 \\
\hline Total & 365
\end{tabular}

Mineral-temper Organic-temper with
mineral inclusions Organic-temper 
Sphericity

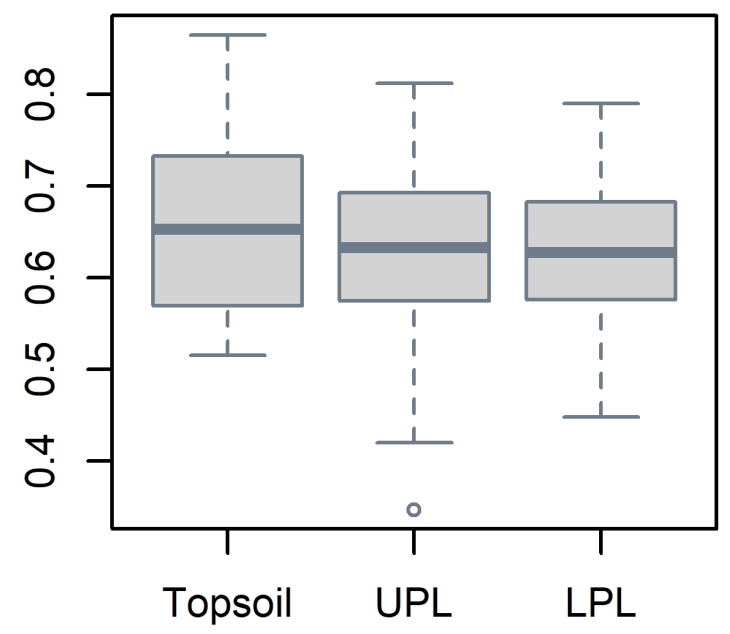

Convexity

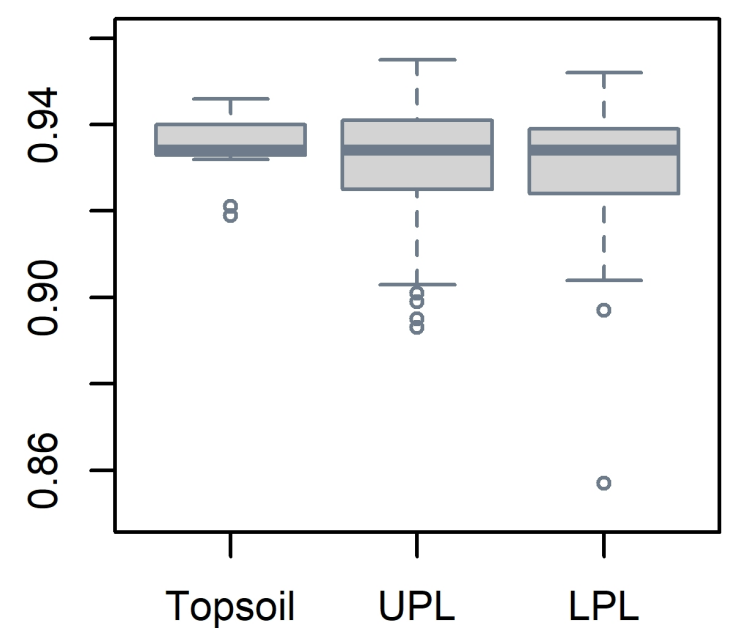

Surface Area $\left(\mathrm{mm}^{2}\right)$

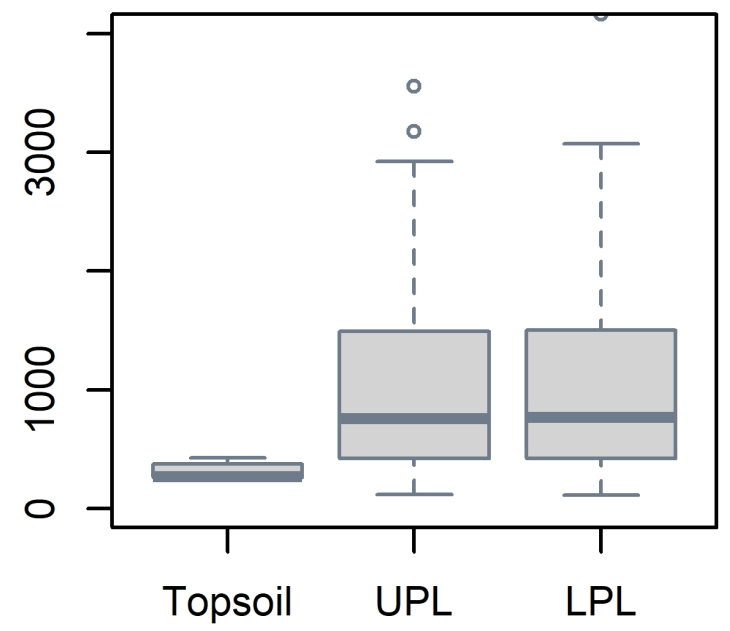

Roundness

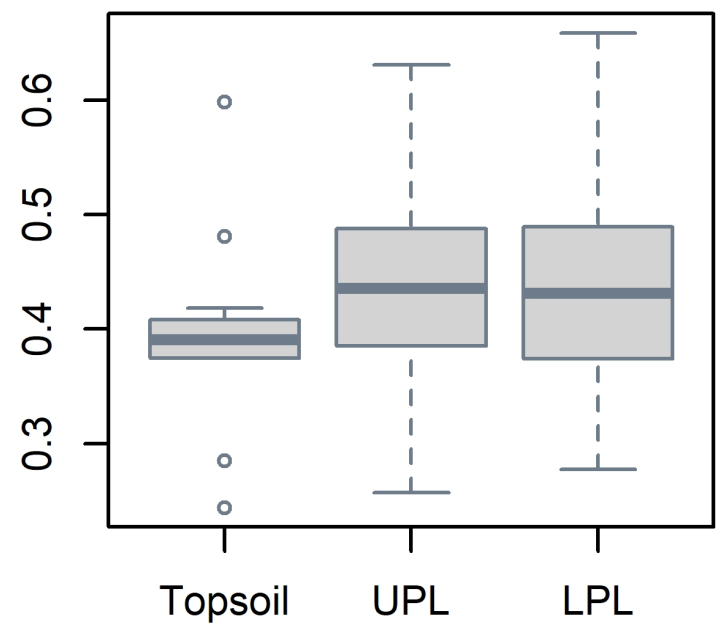

Lenght-to-Thicknes Ratio (S/W)

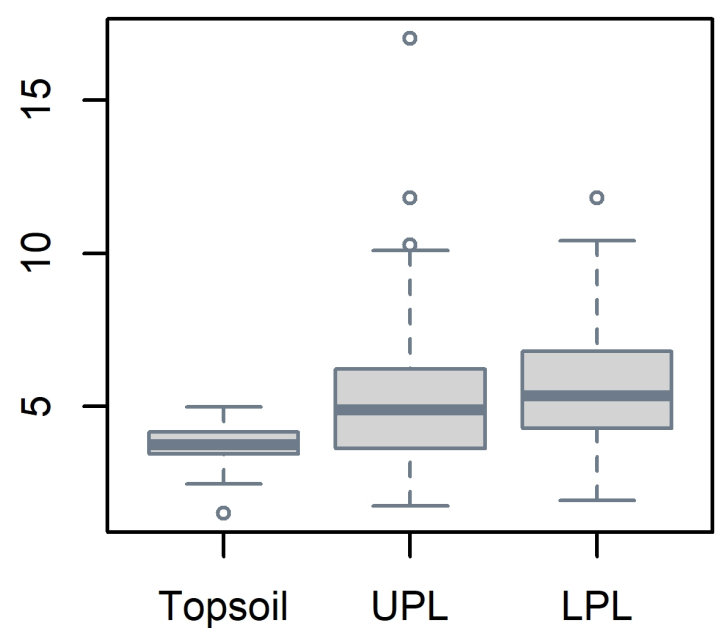

Sample Size ( $n$ )

\begin{tabular}{c|c} 
Topsoil & 11 \\
\hline Upper Pit Layer & 124 \\
\hline Lower Pit Layer & 78 \\
\hline Total & 213
\end{tabular}


Sphericity

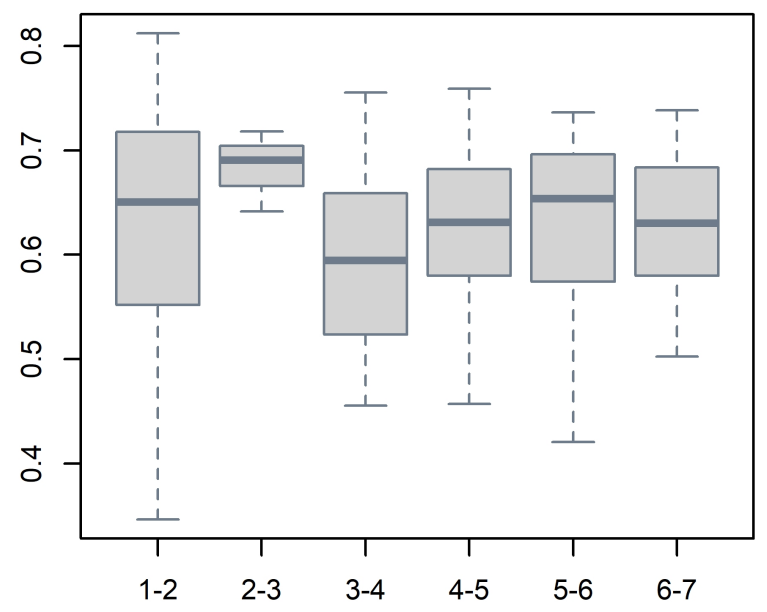

Convexity

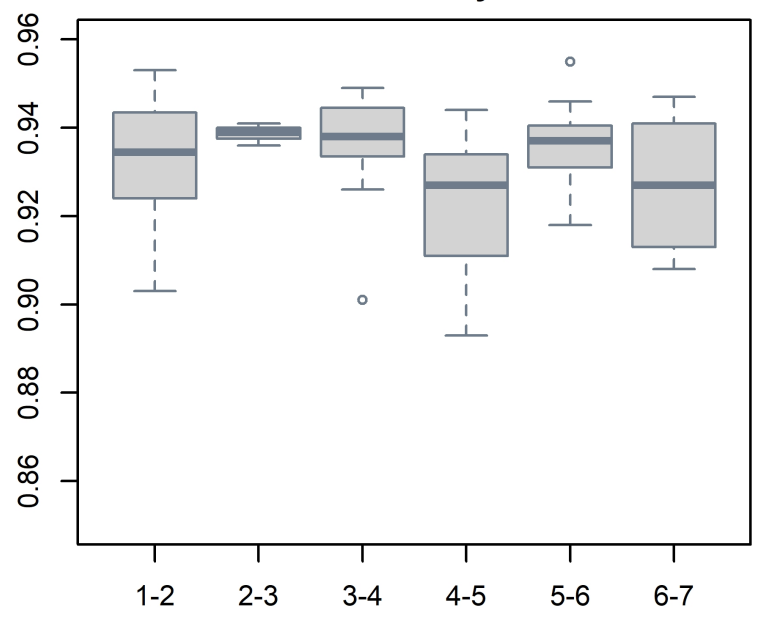

Surface Area $\left(\mathrm{mm}^{2}\right)$

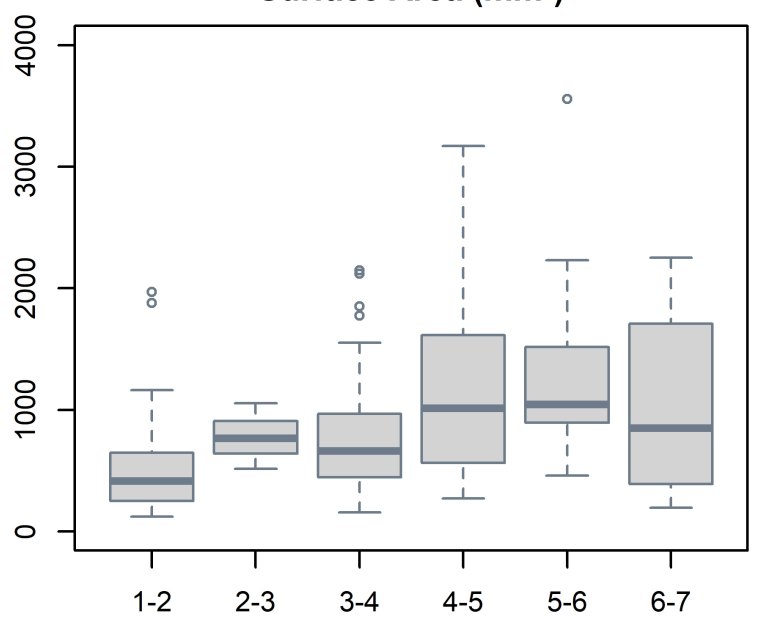

Roundness

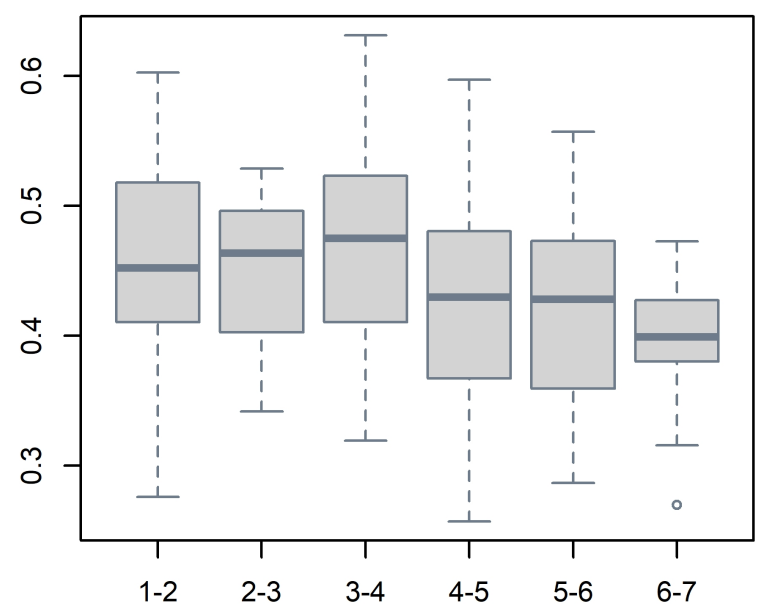

Lenght-to-Thicknes Ratio (S/W)

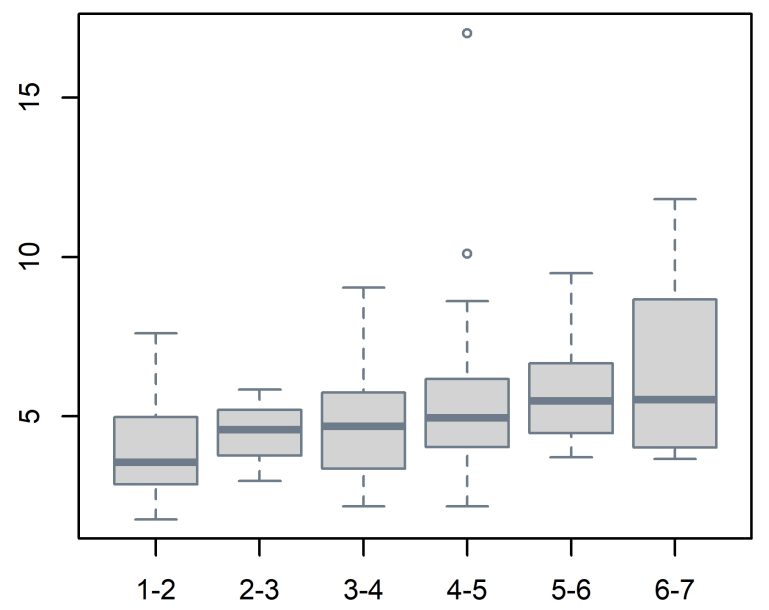

Sample Size (n)

\begin{tabular}{c|c}
$1-2$ & 24 \\
\hline $2-3$ & 3 \\
\hline $3-4$ & 27 \\
\hline $4-5$ & 33 \\
\hline $5-6$ & 19 \\
\hline $6-7$ & 13 \\
\hline Total & 119
\end{tabular}


Sphericity

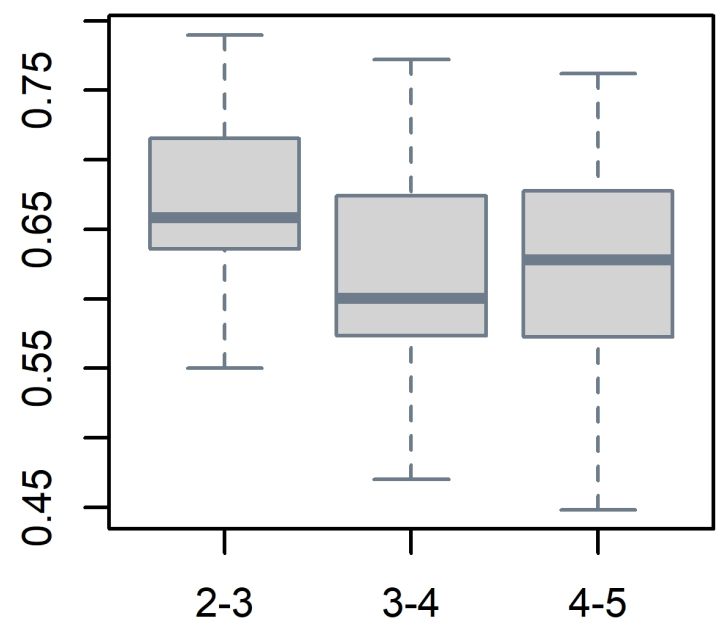

Convexity

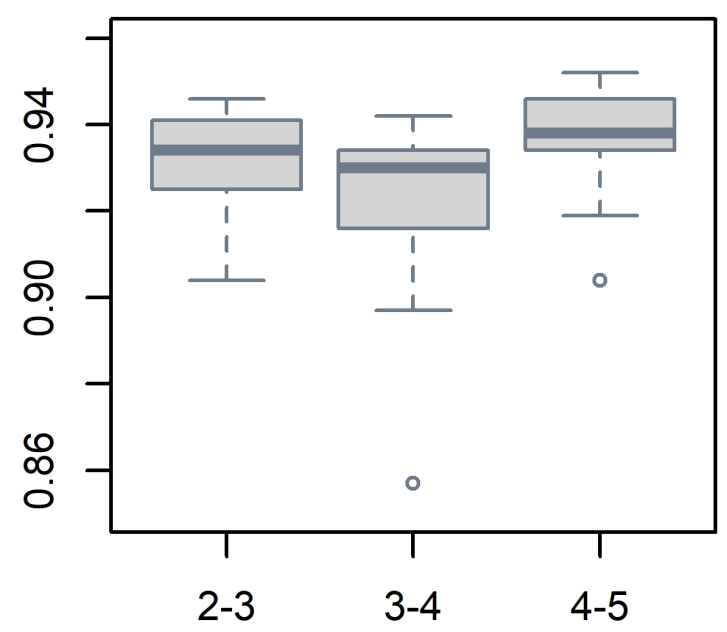

Surface Area $\left(\mathrm{mm}^{2}\right)$

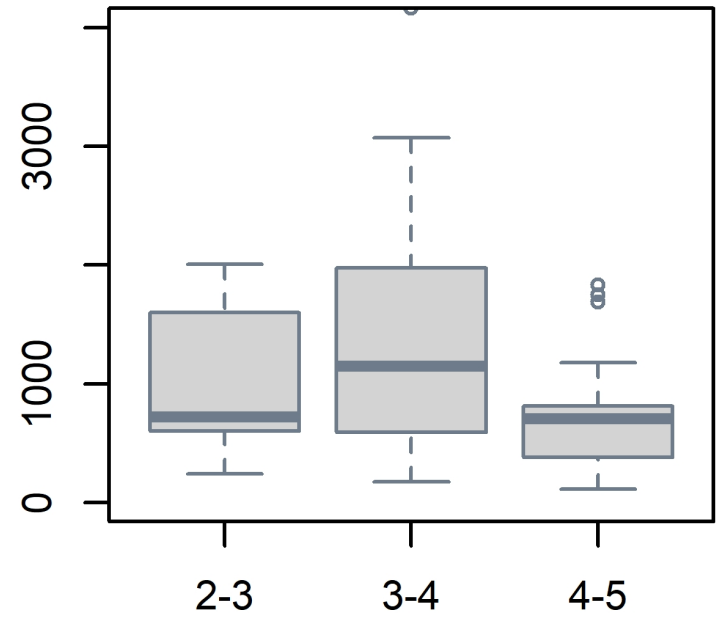

Roundness

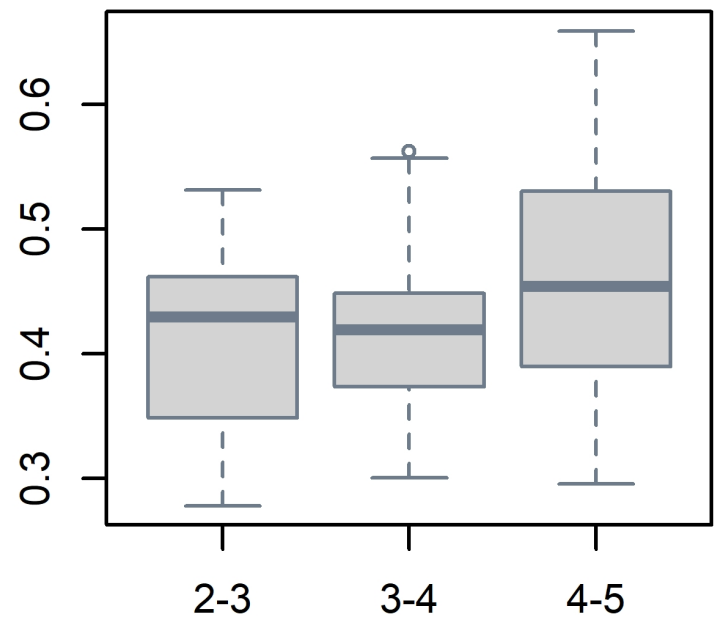

Lenght-to-Thicknes Ratio (S/W)

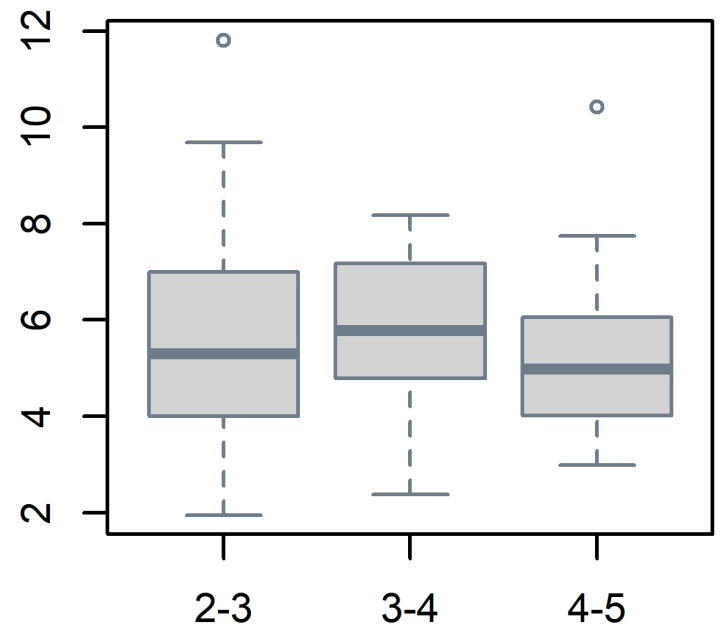

Sample Size (n)

$$
\begin{array}{c|c}
2-3 & 15 \\
\hline 3-4 & 30 \\
\hline 4-5 & 33 \\
\hline \text { Total } & 76
\end{array}
$$




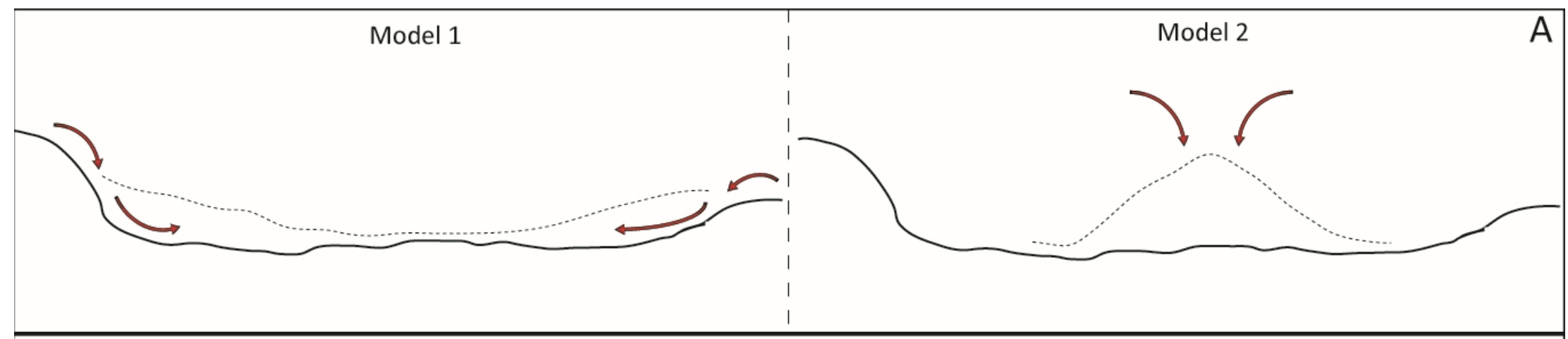

Stage 1

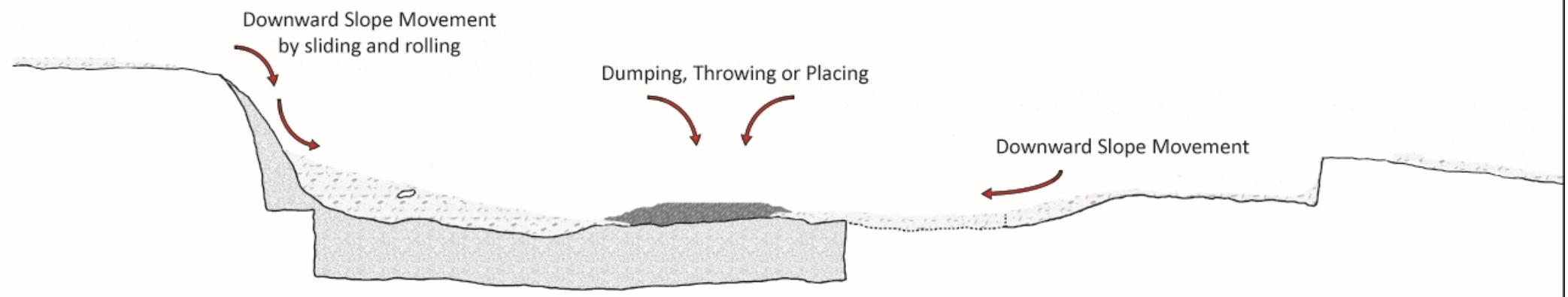

Stage 2

Size Sorting Shape Sorting

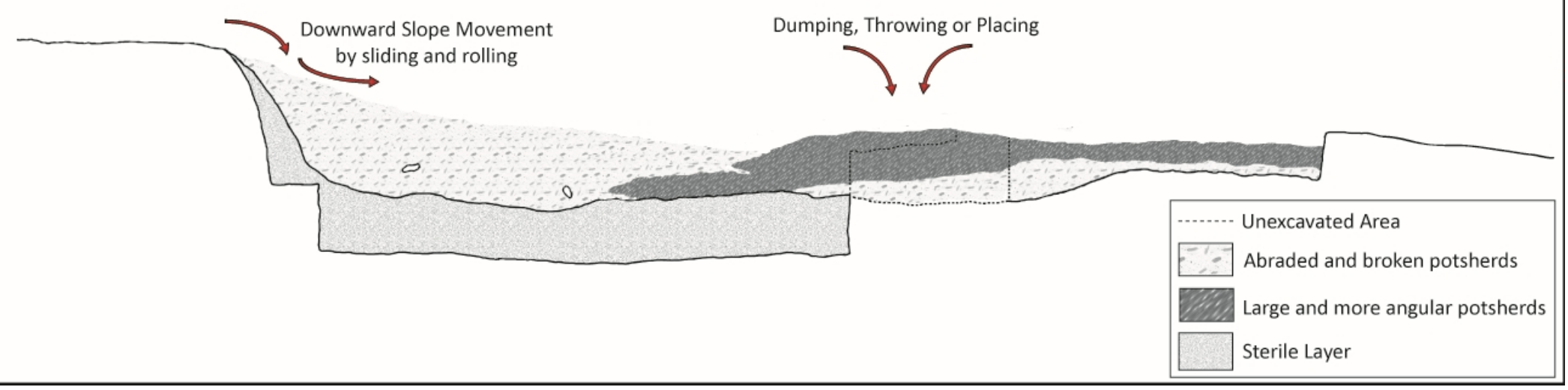



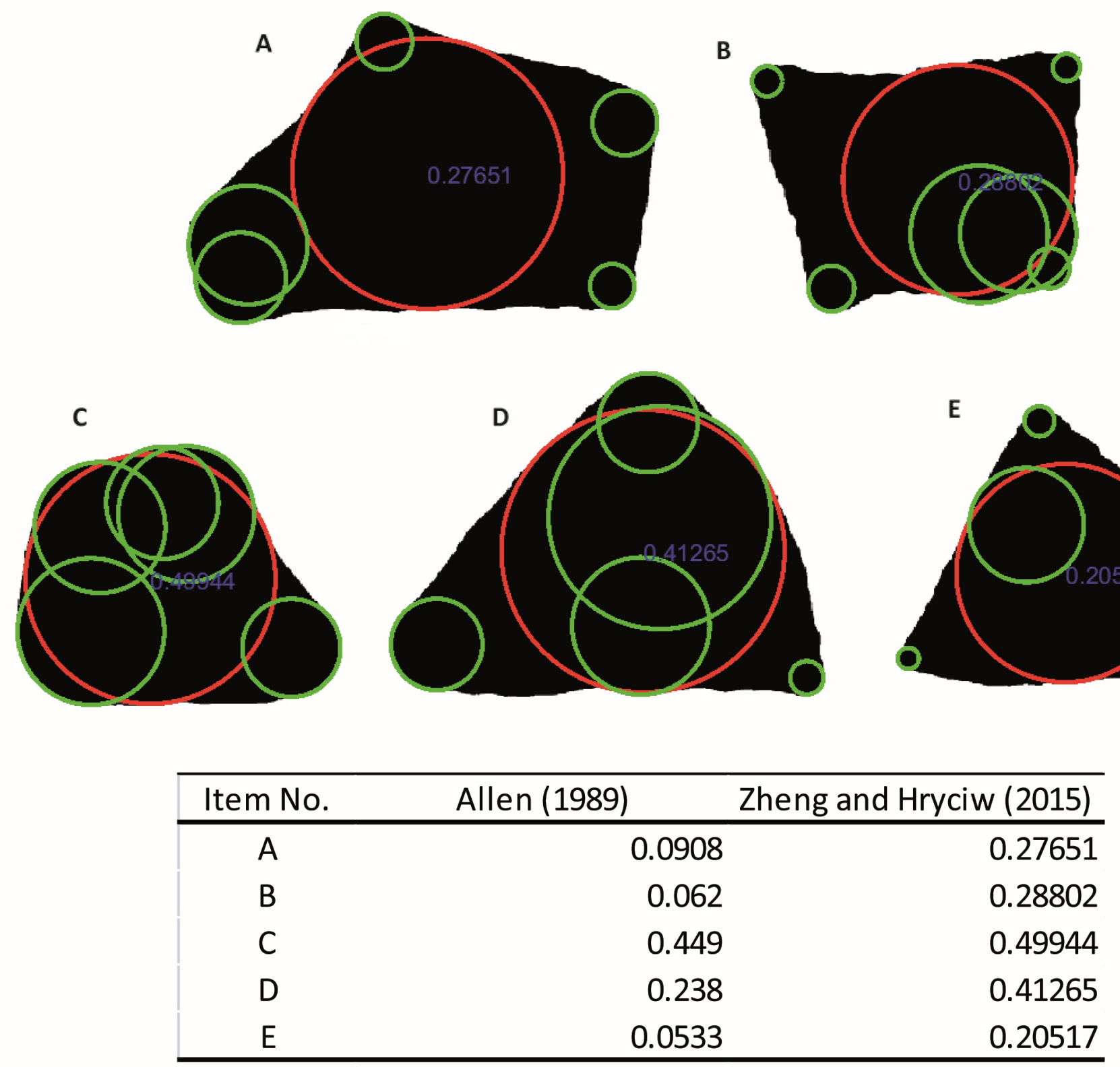